\title{
Vegetative Growth, Yield, and Fruit Quality of Guava (Psidium guajava L.) cv. Maamoura as Affected by Some Biostimulants
}

\author{
Walid F. A. Mosa, ${ }^{\mathrm{a}, *}$ Lidia Sas-Paszt, ${ }^{\mathrm{b}}$ Krzysztof Górnik, ${ }^{\mathrm{b}}$ Hayssam M. Ali, ${ }^{\mathrm{c}}$ and \\ Mohamed Z. M. Salem ${ }^{\text {d,* }}$
}

\begin{abstract}
The present study was performed during two successive seasons 2019 and 2020 to investigate the effect of the soil application of fulvic acid (FA), seaweed extract (SE), and their different combinations on vegetative growth, yield, and fruit quality of six-years-old guava (Psidium guajava L.) cv. 'Maamoura'. The trees were planted $4 \times 4 \mathrm{~m}^{2}$ apart in clay soil under a flood irrigation system. They were treated three times starting from midMarch with one-month intervals with the following treatments: Control (water only), 3 and $4 \mathrm{~g} / \mathrm{L} \mathrm{FA}, 3$ and $4 \mathrm{~g} / \mathrm{L} \mathrm{SE}$, and their different combinations; $3 \mathrm{~g} / \mathrm{L} F A+3 \mathrm{~g} / \mathrm{L} \mathrm{SE}, 3 \mathrm{~g} / \mathrm{L} \mathrm{FA}+4 \mathrm{~g} / \mathrm{L} \mathrm{SE}, 4 \mathrm{~g} / \mathrm{L} \mathrm{FA}+3 \mathrm{~g} / \mathrm{L}$ $\mathrm{SE}$, and $4 \mathrm{~g} / \mathrm{L} \mathrm{FA}+4 \mathrm{~g} / \mathrm{L} \mathrm{SE}$. The results clearly showed that the application of FA or SE solely or in combinations increased shoot length and diameter, as well as leaf chlorophyll compared with the control. The treatments also increased fruit set percentage, fruit yield, and fruit physical and chemical characteristics such as fruit weight, size, TSS\%, total reduced and non-reduced sugars, as well as leaf mineral content, while they decreased the fruit acidity compared with the control in the two seasons.
\end{abstract}

Keywords: Guava; Seaweed extract; Fulvic acid; Yield; Fruit quality; Biostimulant

Contact information: a: Plant Production Department (Horticulture- Pomology), Faculty of Agriculture, Saba Basha, Alexandria University, Alexandria, Egypt; b: Research Institute of Horticulture, Skierniewice, Poland; c: Botany and Microbiology Department, College of Science, King Saud University, P.O. Box 2455, Riyadh 11451, Saudi Arabia; d: Forestry and Wood Technology Department, Faculty of Agriculture (El-Shatby), Alexandria University, Alexandria 21545, Egypt; *Corresponding Authors:

walidbreeder@yahoo.com; zidan_forest@yahoo.com

\section{INTRODUCTION}

Guava (Psidium guajava L.) belongs to the family of Myrtaceae, which is an important subtropical fruit crop. This fruit is rich in ascorbic acid and pectin and has a moderate content of calcium, phosphorus, and other vitamins (Lall et al. 2017).

The application of chemical fertilizers is important in increasing the yield of crops and improving the food security effectively (Ni et al. 2011; Duan et al. 2016; Suhag 2016). However, the excessive usage and the insistence on the use of chemical fertilizers has created some environmental problems, such as soil deterioration, water pollution, destruction of the soil ecology, and reduced fertility of the soil; thus it causes harmful influences on human health (Liu et al. 2013; Stuart et al. 2014; Youssef and Eissa 2014; Sierra et al. 2015; Smith, and Siciliano 2015; Suhag 2016; Uphoff and Dazzo 2016). So, the implementation of the organic substances instead of chemical fertilizers is necessary to raise and maintain soil fertility and health as well as food quality (Suhag 2016; Hui et al. 2017; Ning et al. 2017; Wanga et al. 2018).

Fulvic acid (FA) plays a crucial role in promoting the photosynthesis process. It minimizes the opening of stomata and the transpiration rate, thus minimizing the loss of 
water under well-watered and also drought conditions ( $\mathrm{Lu}$ and Beamish 2001; Li et al. 2005; Anjum et al. 2011; Huang et al. 2020). Besides, the use of FA promotes the growth of roots (Canellas et al. 2002) thereby increasing the uptake of nutrients (Razavi and BahramParvar 2007; Yang et al. 2013; Priya et al. 2014; El-Helaly 2018; Justi et al. 2019; Wang et al. 2019). It was found by Zimmerli et al. (2008) that FA has the ability to remain in the soil under high salt concentration as well as a large range from $\mathrm{pH}$. Wassel et al. (2014) stated that FA has the ability to promote the vegetative growth in plants because it can raise the plants' hormones, such as indole acetic acid, gibberellic acid, and cytokines, as well as antioxidants and vitamins. El-Kenway (2017) performed a study during 2015 and 2016 seasons on 'Thompson seedless' grapevines to investigate the influence of the spray of FA at $500 \mathrm{ppm}$ three times, at the beginning of the growth, after berry with one week set, and at the start of the ripening. The obtained results showed that the application of FA improved the length of shoots, leaf area, and leaf content from total chlorophyll, as well as minerals from nitrogen, phosphorous, and potassium. Moreover, it also raised the obtained yield and fruit physical and chemical characteristics in terms of weight of clusters and berry, berry cohesion, soluble solids percentage, while it reduced the percentages of juice acidity, weight loss of clusters, deterioration, and breaking down of berries compared with control in both experimental seasons. In addition, it was reported that FA enhanced the chlorophyll leaf content, roots dry matter, carbohydrates, and carotenoids (El-Helaly 2018).

Seaweed extract (SE) has a good effect on the time of flowering because of balanced carbohydrate and nitrogen content (Neumann and Zur Nieden 2001) and it contains a large variation of plant growth regulators such as auxins and cytokinin (Zhang and Ervin 2004), as well as organic compounds and polysaccharides (Sivasankari et al. 2006; Rioux et al. 2009). The application of SE to the soil increased the organic carbon, and the uptake of nitrogen, phosphorus, potassium calcium, sulfur, magnesium, zinc, manganese, and iron (Mancuso et al. 2006; Rathore et al. 2009; Zodape et al. 2011) and water content (Kocira et al. 2018). It was found that the foliar spraying of seaweed extracts (SE) was beneficial for four apple cultivars, 'Gala Must', 'Golden Delicious', 'Jonagold Decosta', and 'Elstar'. The spraying was done at the end of bloom, and subsequently four times at intervals of 4 weeks, the last time being about 4 weeks before harvest. Both preparations encouraged shoot and leaf growth, improving the quality of flower formation, extending the time of blooming, as well as raising the percentage of fruit set percentage and the fruit size (Basak 2008). SE could be applied in low quantities as soil or foliar spraying, and it can improve the resistance to insect and pathogen attack and abiotic stress such as drought, frost, salinity, and high or low temperature (Khan et al. 2009; Craigie 2011; Battacharyya et al. 2015; Elansary et al. 2016). Because of the high content of SE from nutrients, hormones, amino acids, vitamins, and antioxidants, it can be defined as a stimulant, which can increase the cell division in plants (Prasad et al. 2010; Colavita et al. 2011). de Sousa et al. (2019) reported that spraying SE on 'Gala' apple cultivars at 0.1, $0.2,0.3,0.4$, and $0.6 \%$ increased the percentage of fruit set, number, weight, and length of fruits compared with control, and the prior treatment was $0.3 \%$. The literature suggests that SE plays an important role in raising the tolerance of stresses, the absorption of minerals, growth, and yield. In addition, it has been shown to reduce seed dormancy and enhance root systems and flowering (Ali et al. 2019).

Therefore, this study was conducted to demonstrate the possibility of depending on

FA and SE as natural sources for the nutrition of fruit trees and safe alternatives to alleviate 
the undesirable effects of chemical fertilizers in increasing water, soil, and environment pollution.

\section{EXPERIMENTAL}

\section{Materials}

This study was conducted at a private orchard located at Abou El Matamir region, Beheira, Governorate, Egypt over two successive seasons 2019 and 2020. The study investigated the effect of the soil application of FA (X-HUMATE Fulvic Acid - 100\% Water Soluble Powder- Humate (Tianjin) International Ltd., Tianjin, China), SE (seaweed extract composition: Alginic acid 15-18\%, Organic matter 45-55\%, Potassium K2O 16\%, N 2.5-3\%, P2O5 4.5-5\% and Water solubility 99.1\% - Hebei Hontai Biotech Co., Ltd., Shijiazhuang, Hebei, China), and their combinations on vegetative growth, yield, and fruit quality of six-year-old guava (Psidium guajava L.) cv. 'Maamoura'.

The trees were about $200 \mathrm{~cm}$ in height and were planted $4 \mathrm{~m} \times 4 \mathrm{~m}$ apart in clay soil under a flood irrigation system. The physicochemical characteristics of the experimental soil according to Sparks et al. (2016) are presented in Table 1. A total of 80 trees, similar in vigor and size, were randomly chosen, arranged in a randomized complete block design (RCBD), and subjected to the same applied agricultural practices in the field during the two seasons. The following treatments of a Control (water only), FA at 3 and 4 $\mathrm{g} / \mathrm{L}$, and SE at 3 and $4 \mathrm{~g} / \mathrm{L}$, as well as their combinations $-3 \mathrm{~g} / \mathrm{L} \mathrm{FA}+3 \mathrm{~g} / \mathrm{L} \mathrm{SE}, 3 \mathrm{~g} / \mathrm{L} \mathrm{FA}$ $+4 \mathrm{~g} / \mathrm{L} \mathrm{SE}, 4 \mathrm{~g} / \mathrm{L} \mathrm{FA}+3 \mathrm{~g} / \mathrm{L} \mathrm{SE}$, and $4 \mathrm{~g} / \mathrm{L} \mathrm{FA}+4 \mathrm{~g} / \mathrm{L} \mathrm{SE}$ - were applied to the trees three times by solubilizing SE or FA. This was done in separate containers and by adding the material to the trees by hand. The study began in mid-March with application intervals of one month. In total, $2 \mathrm{~L}$ of solution for each tree/replicate were employed.

Table 1. Physicochemical Properties for the Soil of the Experiment

\begin{tabular}{|c|c|c|c|c|c|c|c|c|c|}
\hline $\begin{array}{c}\text { Depth } \\
\text { (cm) }\end{array}$ & Texture & $\mathbf{p H}$ & $\begin{array}{c}\text { Electrical } \\
\text { Conductivity } \\
\text { (EC) }(\mathbf{d s} / \mathbf{c m})\end{array}$ & $\mathbf{N}(\%)$ & $\mathbf{P}(\%)$ & $\mathbf{K}(\%)$ & $\begin{array}{c}\mathbf{F e} \\
(\mathbf{m g} / \mathbf{L})\end{array}$ & $\begin{array}{c}\mathbf{Z n} \\
(\mathbf{m g} / \mathbf{L})\end{array}$ & $\begin{array}{c}\mathbf{M n} \\
(\mathbf{m g} / \mathbf{L})\end{array}$ \\
\hline 0 to 60 & Clay & 7.6 & 0.2 & 24.50 & 26.82 & 34.25 & 0.35 & 0.13 & 0.02 \\
\hline
\end{tabular}

Vegetative growth parameters

Starting from the vegetative season, four shoots from each side of each replicate/tree were selected and labeled, whereas, at the end of each growing season, the shoot length and diameter were measured in centimeters. The average leaf area $\left(\mathrm{cm}^{2}\right)$ was determined using the following equation as reported by Demirsoy (2009),

$$
L A=0.70(L x W)-1.06
$$

where LA is a leaf area $\left(\mathrm{cm}^{2}\right), L$ is the maximum length of leaf $(\mathrm{cm})$, and $W$ is the maximum width of the leaf $(\mathrm{cm})$.

Total chlorophyll $\left(\mu \mathrm{Mol} / \mathrm{m}^{2}\right)$ in the fresh leaves was determined as SPAD units by using a Minolta chlorophyll meter (SPAD - 502; Konica Minolta, Osaka, Japan).

Fruit set percentage, fruit yield, and fruit quality

From each side of each tree/replicate, four branches were chosen and labeled 
carefully in March 2019 and 2020. The number of flowers on each branch was calculated, and then the percentage of fruit set was estimated according to Eq. 2:

$$
\text { Fruit set }(\%)=\frac{\text { Number of set fruitlets }}{\text { Number of total flowers }} \times 100
$$

The fruit yield was obtained in October, which is the typical time for harvesting. The yield of each treatment was estimated as fruit weight in $\mathrm{kg}$ per tree and ton per hectare.

The fruit quality was evaluated by sampling 10 fruits per tree/replicate. A total of 80 fruits for each treatment were picked randomly at harvest time in both seasons and then transported to the laboratory of Plant Production Department, Faculty of Agriculture, Saba Basha, Alexandria University, Alexandria, Egypt to determine the fruits' physical and chemical characteristics.

\section{Characterization Methods}

Physical and chemical characteristics of fruits

Fruit weight (g) was estimated by calculating the average weight of 10 fruits from each tree/replicate. Average fruit length, fruit diameter (D), were measured by using a Digital Vernier Caliper (Suzhou Sunrix Precision Tools Co., Ltd., Suzhou, Jiangsu, China).

The fruit volume $\left(\mathrm{cm}^{3}\right)$ was calculated by dipping the fruit in water and weighing the removed water. The pulp weight $(\mathrm{g})$, seed weight $(\mathrm{g})$, juice weight $(\mathrm{g})$, and fruit firmness $\left(\mathrm{Lb} /\right.$ inch $\left.^{2}\right)$ were estimated using a Magness and Taylor pressure tester with a $7 / 18^{-}$ inch plunger using a Magness-Taylor pressure tester (mod. FT 02 (0-2 Lb., Via Reale, 63 - 48011 Alfonsine, Italy). Total soluble solids (TSS) were measured using a hand refractometer (ATAGO CO., LTD., Tokyo, Japan), from the fresh-cut guava fruit. The result was expressed as a percentage $(\%)$. The total and reducing sugars were estimated calorimetrically using the Nelson arsenate-molybdate colorimetric method (Nielsen 2010). Non-reducing sugars were accounted as the value between total sugars and reducing sugars. The titratable acidity (\%) in fruit juice was found using an AOAC method (AOAC 2005) where it was expressed as the amount of citric acid in $\mathrm{g} / 100 \mathrm{mg}$ fruit juice. The TSS/acid ratio was calculated by dividing the value of TSS over the value of titratable acidity. The ascorbic acid content of the juice (Vitamin $\mathrm{C} \mathrm{mg/100} \mathrm{mg}$ juice) was estimated by titration with 2,6 dichloro phenol-indo-phenol (Nielsen 2017) and calculated as mg/100 mL of juice.

\section{Leaves chemical composition}

After the harvest time in November, samples of 30 leaves taken from the middle of vegetative shoots (Arrobas et al. 2018) were randomly selected from each replicate to determine their chemical composition of nitrogen $(\mathrm{N})$, phosphorus $(\mathrm{P})$, and potassium $(\mathrm{K})$. The leaf samples were washed with tap water and then with distilled water, and dried at 70 ${ }^{\circ} \mathrm{C}$ until a constant weight was obtained; finally, the dried leaf samples were ground and acid digested using $\mathrm{H}_{2} \mathrm{SO}_{4}$ and $\mathrm{H}_{2} \mathrm{O}_{2}$ until the digested solution became clear. The digested solution was used for the determination of nitrogen using the micro-Kjeldahl method (Wang et al. 2016), phosphorus by vanadomolybdate method (Weiwei et al. 2017), and potassium using a flame photometer (SKZ International Co., Ltd., Jinan Shandong, China) (Arrobas et al. 2018).

Statistical analysis

The results were statistically analysed using a one-way analysis of variance (ANOVA) according to Ott and Longnecker (2015), and the least significant difference 
(LSD) at $0.05 \%$ was utilized for comparing between the means of treatments and measured with CoHort Software (Pacific Grove, CA, USA).

\section{RESULTS AND DISCUSSION}

\section{Vegetative Growth Parameters}

Data in Table 2 show that shoot length, shoot diameter, leaf area, and leaf total chlorophyll content were significantly increased by the soil application of SE or FA individually or in combination compared to the control in both two seasons. Moreover, the obtained results showed that the combination between FA and SE was more effective than the usage of each one of them individually. The highest increments were obtained by the soil application of $4 \mathrm{~g} / \mathrm{L}$ FA combined with $3 \mathrm{~g}$ or $4 \mathrm{~g} / \mathrm{L} \mathrm{SE}$ in both experimental seasons.

These results agree with the previous findings of Piccolo and Mbagwu (1999). They reported that due to the structure of $\mathrm{FA}$, which contains groups of $\mathrm{COOH}, \mathrm{OH}$, and phenolic compounds, it can improve the soil texture, fertility, and stability. Moreover, FA can increase the chemical elements uptake, particularly those that engaged in the process of photosynthesis like iron, zinc, and manganese (Mackowiak et al. 2001; Nardi et al. 2002; Eyheraguibel et al. 2008; Yang et al. 2013; Wang et al. 2019). Besides, FA also plays an important role in increasing length and number of root hairs in plants (Canellas et al. 2002; Schmidt et al. 2007), the rate of photosynthesis, and minimizing the opening of stomata, transpiration rate, and water loss so it can stimulate the growth of plants under drought and water lack conditions (Li et al. 2005; Anjum et al. 2011; Huang et al. 2020).

Table 2. Influence of Soil Application of SE and FA on Shoot Length, Shoot Diameter, Leaf Area, and Leaf Total Chlorophyll in Guava cv. Maamoura

\begin{tabular}{|c|c|c|c|c|c|c|c|c|}
\hline \multirow[t]{2}{*}{ Treatment } & \multicolumn{2}{|c|}{$\begin{array}{l}\text { Shoot Length } \\
(\mathrm{cm})\end{array}$} & \multicolumn{2}{|c|}{$\begin{array}{l}\text { Shoot Diameter } \\
(\mathrm{mm})\end{array}$} & \multicolumn{2}{|c|}{$\begin{array}{l}\text { Leaf Area } \\
\quad\left(\mathrm{cm}^{2}\right)\end{array}$} & \multicolumn{2}{|c|}{$\begin{array}{c}\text { Total Chlorophyll } \\
\text { SPAD } \\
\left(\mu \mathrm{Mol} \mathrm{m}^{-2}\right)\end{array}$} \\
\hline & 2019 & 2020 & 2019 & 2020 & 2019 & 2020 & 2019 & 2020 \\
\hline Control & $\begin{array}{c}22.73 e \\
\pm 1.51\end{array}$ & $\begin{array}{c}24.73 \mathrm{e} \\
\pm 0.3\end{array}$ & $\begin{array}{l}2.19 f \\
\pm 0.04\end{array}$ & $\begin{array}{l}2.30 \mathrm{~g} \\
\pm 0.04\end{array}$ & $\begin{array}{l}35.44 f \\
\pm 0.93\end{array}$ & $\begin{array}{l}38.50 f \\
\pm 1.6\end{array}$ & $\begin{array}{l}41.11 \mathrm{e} \\
\pm 96\end{array}$ & $\begin{array}{l}43.20 f \\
\pm 0.03\end{array}$ \\
\hline $3 \mathrm{~g} / \mathrm{L} \mathrm{FA}$ & $\begin{array}{l}24.7 d \\
\pm 1.00\end{array}$ & $\begin{array}{c}27.71 \mathrm{~cd} \\
\pm 1.03\end{array}$ & $\begin{array}{l}2.78 \mathrm{e} \\
\pm 0.02 \\
\end{array}$ & $\begin{array}{l}3.16 \mathrm{e} \\
\pm 0.01\end{array}$ & $\begin{array}{c}44.03 d \\
\pm 0.59\end{array}$ & $\begin{array}{c}46.87 \mathrm{de} \\
\pm 0.52\end{array}$ & $\begin{array}{c}45.05 d \\
\pm 0.69\end{array}$ & $\begin{array}{c}46.52 e \\
\pm 1.02 \\
\end{array}$ \\
\hline $4 \mathrm{~g} / \mathrm{L} \mathrm{FA}$ & $\begin{array}{l}27.73 \mathrm{c} \\
\pm 1.06\end{array}$ & $\begin{array}{l}29.56 \mathrm{c} \\
\pm 1.16\end{array}$ & $\begin{array}{l}2.90 \mathrm{~d} \\
\pm 0.07\end{array}$ & $\begin{array}{l}3.29 d \\
\pm 0.04\end{array}$ & $\begin{array}{l}46.21 \mathrm{c} \\
\pm 0.57\end{array}$ & $\begin{array}{l}51.96 \mathrm{c} \\
\pm 1.48\end{array}$ & $\begin{array}{l}49.99 \mathrm{~b} \\
\pm 1.58\end{array}$ & $\begin{array}{l}51.73 \mathrm{c} \\
\pm 0.75\end{array}$ \\
\hline $3 \mathrm{~g} / \mathrm{L} \mathrm{SE}$ & $\begin{array}{c}24.63 d \\
\pm 0.94\end{array}$ & $\begin{array}{l}27.63 d \\
\pm 1.01\end{array}$ & $\begin{array}{l}2.78 e \\
\pm 0.06\end{array}$ & $\begin{array}{l}2.77 f \\
\pm 0.08\end{array}$ & $\begin{array}{l}42.3 e \\
\pm 0.98\end{array}$ & $\begin{array}{c}45.28 \mathrm{e} \\
\pm 1.08\end{array}$ & $\begin{array}{l}43.73 d \\
\pm 0.55\end{array}$ & $\begin{array}{c}45.41 e \\
\pm 0.25\end{array}$ \\
\hline $4 \mathrm{~g} / \mathrm{L} \mathrm{SE}$ & $\begin{array}{c}27.66 \mathrm{c} \\
\pm 1.09\end{array}$ & $\begin{array}{c}27.94 \mathrm{~cd} \\
\pm 1.57\end{array}$ & $\begin{array}{l}2.79 e \\
\pm 0.05\end{array}$ & $\begin{array}{c}3.22 \mathrm{de} \\
\pm 0.04\end{array}$ & $\begin{array}{c}45.32 \mathrm{~cd} \\
\pm 1.28\end{array}$ & $\begin{array}{c}48.79 d \\
\pm 1.34\end{array}$ & $\begin{array}{c}47.07 \mathrm{c} \\
\pm 0.5\end{array}$ & $\begin{array}{c}48.81 d \\
\pm 1.33\end{array}$ \\
\hline $\begin{array}{c}3 \mathrm{~g} / \mathrm{L} \mathrm{FA}+ \\
3 \mathrm{~g} / \mathrm{L} \mathrm{SE}\end{array}$ & $\begin{array}{c}28.66 \mathrm{bc} \\
\pm 0.96\end{array}$ & $\begin{array}{c}32.00 \mathrm{~b} \\
\pm 0.16 \\
\end{array}$ & $\begin{array}{l}3.58 \mathrm{c} \\
\pm 0.06 \\
\end{array}$ & $\begin{array}{l}3.61 \mathrm{c} \\
\pm 0.04 \\
\end{array}$ & $\begin{array}{c}46.61 \mathrm{c} \\
0.96\end{array}$ & $\begin{array}{c}54.28 \mathrm{~b} \\
\pm 0.98 \\
\end{array}$ & $\begin{array}{c}50.39 \mathrm{~b} \\
\pm 1.01 \\
\end{array}$ & $\begin{array}{c}52.01 \mathrm{c} \\
\pm 0.67 \\
\end{array}$ \\
\hline $\begin{array}{c}3 \mathrm{~g} / \mathrm{L} \mathrm{FA}+ \\
4 \mathrm{~g} / \mathrm{L} \mathrm{SE}\end{array}$ & $\begin{array}{c}29.66 b \\
\pm 1.12\end{array}$ & $\begin{array}{l}32.08 \mathrm{~b} \\
\pm 1.01\end{array}$ & $\begin{array}{l}3.73 b \\
\pm 0.04\end{array}$ & $\begin{array}{l}3.76 \mathrm{~b} \\
\pm 0.6\end{array}$ & $\begin{array}{c}46.82 \mathrm{c} \\
\pm 0.94\end{array}$ & $\begin{array}{c}56.70 \mathrm{a} \\
\pm 1.10\end{array}$ & $\begin{array}{c}50.39 \mathrm{~b} \\
\pm 1.59\end{array}$ & $\begin{array}{l}53.26^{\text {bc }} \\
\pm 1.55\end{array}$ \\
\hline $\begin{array}{c}4 \mathrm{~g} / \mathrm{L} \mathrm{FA}+ \\
3 \mathrm{~g} / \mathrm{L} \mathrm{SE}\end{array}$ & $\begin{array}{c}32.11 \mathrm{a} \\
\pm 0.97\end{array}$ & $\begin{array}{c}33.04 b \\
\pm 1.21\end{array}$ & $\begin{array}{c}3.81 a b \\
\pm 0.04\end{array}$ & $\begin{array}{l}4.16 a \\
\pm 0.01\end{array}$ & $\begin{array}{c}48.89 b \\
\pm 104\end{array}$ & $\begin{array}{c}57.25 a \\
\pm 0.96\end{array}$ & $\begin{array}{c}52.89 a \\
\pm 0.65\end{array}$ & $\begin{array}{c}53.70 \mathrm{~b} \\
\pm 0.59\end{array}$ \\
\hline $\begin{array}{c}4 \mathrm{~g} / \mathrm{L} \text { FA + } \\
4 \mathrm{~g} / \mathrm{L} \mathrm{SE}\end{array}$ & $\begin{array}{c}33.61 a \\
\pm 0.96\end{array}$ & $\begin{array}{c}35.57 a \\
\pm 0.94\end{array}$ & $\begin{array}{l}3.82 \mathrm{a} \\
\pm 0.02\end{array}$ & $\begin{array}{l}4.16 a \\
\pm 0.04\end{array}$ & $\begin{array}{c}53.78 a \\
\pm 1.16\end{array}$ & $\begin{array}{c}57.88 a \\
\pm 1.44\end{array}$ & $\begin{array}{c}54.29 a \\
\pm 0.97\end{array}$ & $\begin{array}{c}56.57 a \\
\pm 0.83\end{array}$ \\
\hline $\mathrm{LSD}_{0.05}$ & 1.87 & 1.85 & 0.09 & 0.08 & 1.71 & 2.15 & 1.73 & 1.60 \\
\hline
\end{tabular}


In the same trend, it was reported that because SE contains a high content from micro and macronutrients, such as iron, copper, sulfur, manganese, nitrogen, phosphorous, and gibberellic acid, indole acidic acid, cytokines, and amino acids. So, it could be classified as a biostimulant for the growth of the plant and has a great ability to enhance the plant cell division (Abdel-Mawgoud et al. 2010; Prasad et al. 2010; Hayyawi et al. 2020), as well as magnesium, which is very important for the synthesis of chlorophyll (Almaroai and Eissa 2020). Besides, it was reported that FA can increase the plant growth because its effect, which is similar to that of auxin, gerbilline, and cytokinin (Samavat and Samavat 2014). Additionally, the foliar application of FA was also more effective in improving leaf area and shoot length in apple (Taha et al. 2016; Khan et al. 2019). The application of SE enhanced leaf total chlorophyll, photosynthesis, transpiration, and the conductance of stomata (Fan et al. 2013; Al-Ghamdi and Elansary 2018; Rouphael et al. 2018; Kulkarni et al. 2019).

\section{Fruit Set Percentage and Fruit Yield}

Results in Table 3 make it clear that fruit set percentage, fruit yield in kg per tree, and fruit yield in ton per hectare were significantly enhanced by the soil application of SE or FA at 3 or $4 \mathrm{~g} / \mathrm{L}$ individually or in combinations. This may be due to the role of SE and FA in improving the vegetative growth parameters and leaf total chlorophyll as well as improving the availability of nutrients. The results showed also that mixing FA with SE was more effective in their effect than the individual application in the two seasons. The combination of $4 \mathrm{~g} / \mathrm{L} \mathrm{FA}$ with $4 \mathrm{~g} / \mathrm{L} \mathrm{SE}$ was the superior treatment as compared to the control and the other applied treatments in both experimental seasons. Additionally, fruit set and yield were significantly increased by the combinations of $3 \mathrm{~g} / \mathrm{L} \mathrm{FA}+4 \mathrm{~g} / \mathrm{L} \mathrm{SE}$ and $4 \mathrm{~g} / \mathrm{L} \mathrm{FA}+3 \mathrm{~g} / \mathrm{L} \mathrm{SE}$, in the two seasons compared with control. These results were previously explained in several studies (Stirk et al. 2003; Craigie 2011; Gupta et al. 2011; Khan et al. 2011; Stirk and Van Staden, 2014; Battacharyya et al. 2015; Aremu et al. 2016; Patel et al. 2018; Renaut et al. 2019; Yalçın et al. 2019; Al-Juthery et al. 2020). These groups reported that, as SEs are rich in polysaccharides, auxins, gibberellins, cytokinins, indole-3-acetic acid (IAA), vitamins, oils, fats, acids, amino acids, polyphenols antioxidants, pigments, antimicrobial factors, $\mathrm{Fe}, \mathrm{Cu}, \mathrm{Zn}, \mathrm{Co}, \mathrm{Mo}, \mathrm{Mn}$, and $\mathrm{Ni}$, they can improve the yield and yield components.

The foliar application of fulvic acid was more effective in improving the fruit set percentage and yield in $\mathrm{kg} /$ tree in apple (Basak 2008; Khan et al. 2019). In the same trend, it was reported previously that the application of SEs increased the flower set percentage and fruit yield in "Koroneiki" olive cultivar (Chouliaras et al. 2009), in pear (Calvo et al. 2014) and in "Fagri Kalan" mango cultivar (El-Sharony et al. 2015). Besides, SE enhanced the plant resistance to biotic (Machado et al. 2014; Ben Salah et al. 2018) and abiotic stress (Bradáčová et al. 2016; Cabo et al. 2019; Khompatara et al. 2019), stimulated the growth of crops, and increased yield (Renaut et al. 2019; El Boukhari et al. 2020). In addition, treating orange with SEs increased the maturity index and yield, while it decreased the fruit drop (Arioli et al. 2015; Gomathi, et al. 2017). Spraying SE on apple (Malus domestica L.) increased fruit set and fruit yield (Soppelsa et al. 2018; Valencia et al. 2018; de Sousa et al. 2019). The application of SEs at $0,2,4$, and $8 \mathrm{gL}^{-1}$ on 'Albion' strawberry cultivar via fertigation system increased the number of flowers per plant, and the yield, compared with the control, was also increased (Al-Shatri et al. 2020). 
Table 3. Influence of Soil Application of SE and FA on Fruit Set Percentages, Fruit Yield in kg per Tree, and Fruit Yield in Ton per Hectare in Guava cv. Maamoura

\begin{tabular}{|c|c|c|c|c|c|c|}
\hline \multirow{2}{*}{ Treatment } & \multicolumn{2}{|c|}{ Fruit Set (\%) } & \multicolumn{2}{c|}{ Fruit Yield (kg/Tree) } & \multicolumn{2}{c|}{ Yield (ton)/Hectare } \\
\cline { 2 - 7 } & $\mathbf{2 0 1 9}$ & $\mathbf{2 0 2 0}$ & $\mathbf{2 0 1 9}$ & $\mathbf{2 0 2 0}$ & $\mathbf{2 0 1 9}$ & $\mathbf{2 0 2 0}$ \\
\hline \multirow{2}{*}{ Control } & $54.9 \mathrm{~d}$ & $58.95 \mathrm{f}$ & $40.52 \mathrm{f}$ & $46.19 \mathrm{f}$ & $24.31 \mathrm{f}$ & $27.72 \mathrm{f}$ \\
& \pm 0.54 & \pm 1.45 & \pm 2.03 & \pm 2.65 & \pm 1.22 & \pm 1.59 \\
\hline \multirow{2}{*}{$3 \mathrm{~g} / \mathrm{L} \mathrm{FA}$} & $67.2 \mathrm{bc}$ & $66.39 \mathrm{e}$ & $61.28 \mathrm{~d}$ & $66.96 \mathrm{de}$ & $36.77 \mathrm{~d}$ & $40.18 \mathrm{de}$ \\
& \pm 1.43 & \pm 0.68 & \pm 1.32 & \pm 1.5 & \pm 0.79 & \pm 0.90 \\
\hline \multirow{2}{*}{$4 \mathrm{~g} / \mathrm{L} \mathrm{FA}$} & $68.72 \mathrm{~b}$ & $68.69 \mathrm{~cd}$ & $65.31 \mathrm{c}$ & $72.64 \mathrm{bc}$ & $39.19 \mathrm{c}$ & $43.59 \mathrm{bc}$ \\
& \pm 1.24 & \pm 1.41 & \pm 1.04 & \pm 1.90 & \pm 0.63 & \pm 1.14 \\
\hline \multirow{2}{*}{$3 \mathrm{~g} / \mathrm{L} \mathrm{SE}$} & $66.37 \mathrm{c}$ & $65.25 \mathrm{e}$ & $58.48 \mathrm{e}$ & $65.4 \mathrm{e}$ & $35.09 \mathrm{e}$ & $39.24 \mathrm{e}$ \\
& \pm 0.97 & \pm 1.59 & \pm 1.80 & \pm 1.13 & \pm 1.08 & \pm 0.67 \\
\hline $4 \mathrm{~g} / \mathrm{L} \mathrm{SE}$ & $67.78 \mathrm{bc}$ & $67.49 \mathrm{de}$ & $64.27 \mathrm{c}$ & $70.2 \mathrm{~cd}$ & $38.56 \mathrm{c}$ & $42.12 \mathrm{~cd}$ \\
& \pm 2.00 & \pm 1.02 & \pm 1.24 & \pm 3.08 & \pm 0.74 & \pm 1.85 \\
\hline $3 \mathrm{~g} / \mathrm{L} \mathrm{FA} \mathrm{+} \mathrm{3} \mathrm{g/L}$ & $69.03 \mathrm{~b}$ & $70.65 \mathrm{bc}$ & $71.05 \mathrm{~b}$ & $74.25 \mathrm{~b}$ & $42.63 \mathrm{~b}$ & $44.55 \mathrm{~b}$ \\
$\mathrm{SE}$ & \pm 1.78 & \pm 0.11 & \pm 1.23 & \pm 0.86 & \pm 0.74 & \pm 0.52 \\
\hline $3 \mathrm{~g} / \mathrm{L} \mathrm{FA}+4 \mathrm{~g} / \mathrm{L}$ & $71.67 \mathrm{a}$ & $71.09 \mathrm{~b}$ & $72.34 \mathrm{~b}$ & $75.93 \mathrm{~b}$ & $43.40 \mathrm{~b}$ & $45.56 \mathrm{~b}$ \\
$\mathrm{SE}$ & \pm 1.76 & \pm 1.10 & \pm 2.11 & \pm 2.50 & \pm 1.27 & \pm 1.50 \\
\hline $4 \mathrm{~g} / \mathrm{L} \mathrm{FA}+3 \mathrm{~g} / \mathrm{L}$ & $72.09 \mathrm{a}$ & $71.49 \mathrm{~b}$ & $73.52 \mathrm{~b}$ & $81.65 \mathrm{a}$ & $44.11 \mathrm{~b}$ & $48.99 \mathrm{a}$ \\
$\mathrm{SE}$ & \pm 1.73 & \pm 1.82 & \pm 1.98 & \pm 3.18 & \pm 1.19 & \pm 1.90 \\
\hline $4 \mathrm{~g} / \mathrm{L} \mathrm{FA}+4 \mathrm{~g} / \mathrm{L}$ & $72.83 \mathrm{a}$ & $74.33 \mathrm{a}$ & $76.29 \mathrm{a}$ & $83.25 \mathrm{a}$ & $45.77 \mathrm{a}$ & $49.95 \mathrm{a}$ \\
$\mathrm{SE}$ & \pm 0.85 & \pm 1.57 & \pm 0.82 & \pm 0.64 & \pm 0.49 & \pm 0.39 \\
\hline LSD 0.05 & 2.31 & 2.27 & 2.60 & 3.83 & 1.56 & 2.30 \\
\hline Means not sharing the same letter(s) within each column are significantly different at 0.05 level \\
of significance
\end{tabular}

\section{Fruit Physical Characteristics}

The data shown in Table 4 demonstrates that fruit weight, volume, length, and diameter were significantly increased by the soil application of FA or SE at 3 or $4 \mathrm{~g} / \mathrm{L}$ alone or in combination with the other in the two seasons compared to the control. Moreover, the same fruit physical characteristics were increased with the combinations of FA at 3 or 4 $\mathrm{g} / \mathrm{L}$ with $\mathrm{SE}$ at 3 or 4 rather than the usage of FA, SE alone, or control treatment in both experimental seasons. It was noticed that the effect of $4 \mathrm{~g} / \mathrm{L} \mathrm{FA}+4 \mathrm{~g} \mathrm{SE}$ combination was superior in comparison with $4 \mathrm{~g} / \mathrm{L} \mathrm{FA}+3 \mathrm{~g} \mathrm{SE}, 3 \mathrm{~g} / \mathrm{L} \mathrm{FA}+4 \mathrm{~g} \mathrm{SE}$, and $3 \mathrm{~g} / \mathrm{L} \mathrm{FA}+3 \mathrm{~g} \mathrm{SE}$ combinations as compared to control in both experimental seasons. Similar results were obtained by El-Boray et al. (2015). They reported that spraying 'Superior seedless' grape cultivar with FA at $9 \mathrm{~mL} / \mathrm{L}$ per vine significantly increased the average cluster weight, size, length, and width. Additionally, the foliar application of FA was more effective in improving fruit weight, fruit length, and diameter in apricot (Haggag et al. 2016). AlMusawi (2018) stated that the spraying of sour orange with algae extracts increased fruit weight, length, width, and size, width and weight of peel, and moisture content in fruit and peel. Al-Shatri et al. (2020) reported that the application of SEs at 0,2 , 4, and $8 \mathrm{gL}^{-1}$ on 'Albion' strawberry cultivar via fertigation system increased fruit weight and volume, as compared with control. The obtained results also agree with the prior findings of Harhash et al (2021a). They reported that the foliar application of 'Flame seedless' grape trees with FA at 1000, 1500, and 2000 ppm, and SE at 2000, 3000, and 4000 ppm, before flowering, during the full bloom, and three weeks later improved weight, length, width, size, and number of clusters as well as the weight of 100 berries as compared to control. The current results are in agreement with the findings of Harhash et al. (2021b). They found that spraying pomegranate cultivar cv. 'Wonderful' at the beginning of flowering, full bloom, 
and one month later three times with FA at $0.2 \%, 0.3 \%$, and $0.4 \%$, improved weight, size, length, number, and width of fruit.

Table 4. Influence of Soil Application of SE and FA on Fruit Weight, Volume, Length, and Diameter of Guava cv. Maamoura

\begin{tabular}{|c|c|c|c|c|c|c|c|c|}
\hline \multirow[t]{2}{*}{ Treatment } & \multicolumn{2}{|c|}{ Fruit Weight (g) } & \multicolumn{2}{|c|}{ Fruit Volume $\left(\mathrm{cm}^{3}\right)$} & \multicolumn{2}{|c|}{$\begin{array}{l}\text { Fruit Length } \\
\text { (cm) }\end{array}$} & \multicolumn{2}{|c|}{$\begin{array}{l}\text { Fruit Diameter } \\
\text { (cm) }\end{array}$} \\
\hline & 2019 & 2020 & 2019 & 2020 & 2019 & 2020 & 2019 & 2020 \\
\hline Control & $\begin{array}{c}136.96 \mathrm{e} \\
\pm 1.58\end{array}$ & $\begin{array}{c}143.48 f \\
\pm 1.60\end{array}$ & $\begin{array}{c}149.68 \mathrm{e} \\
\pm 0.15\end{array}$ & $\begin{array}{c}154.88 \mathrm{~d} \\
\pm 4.49\end{array}$ & $\begin{array}{l}7.17 \mathrm{~g} \\
\pm 0.06\end{array}$ & $\begin{array}{l}7.18 \mathrm{~g} \\
\pm 0.04\end{array}$ & $\begin{array}{l}4.37 e \\
\pm 0.12\end{array}$ & $\begin{array}{l}4.38 f \\
\pm 0.03\end{array}$ \\
\hline $3 \mathrm{~g} / \mathrm{L} \mathrm{FA}$ & $\begin{array}{c}155.43 \mathrm{~cd} \\
\pm 1.79\end{array}$ & $\begin{array}{c}156.82 \mathrm{de} \\
\pm 2.35\end{array}$ & $\begin{array}{c}166.2 \mathrm{~d} \\
\pm 2.59\end{array}$ & $\begin{array}{c}171.62 \mathrm{c} \\
\pm 1.85\end{array}$ & $\begin{array}{l}8.35 \mathrm{e} \\
\pm 0.02\end{array}$ & $\begin{array}{l}8.46 \mathrm{e} \\
\pm 0.03\end{array}$ & $\begin{array}{l}5.20 \mathrm{c} \\
\pm 0.07\end{array}$ & $\begin{array}{c}5.3 d \\
\pm 0.06\end{array}$ \\
\hline $4 \mathrm{~g} / \mathrm{L} \mathrm{FA}$ & $\begin{array}{c}161.48 b \\
\pm 2.65\end{array}$ & $\begin{array}{c}162.93 \mathrm{c} \\
\pm 0.36\end{array}$ & $\begin{array}{c}172.23 \mathrm{c} \\
\pm 4.30\end{array}$ & $\begin{array}{c}174.97 \mathrm{bc} \\
\pm 1.51\end{array}$ & $\begin{array}{l}8.5 \mathrm{~cd} \\
\pm 0.06\end{array}$ & $\begin{array}{c}8.55 \mathrm{cde} \\
\pm 0.06\end{array}$ & $\begin{array}{l}5.48 \mathrm{~b} \\
\pm 0.03\end{array}$ & $\begin{array}{c}5.56 \mathrm{bc} \\
\pm 0.01\end{array}$ \\
\hline $3 \mathrm{~g} / \mathrm{L} \mathrm{SE}$ & $\begin{array}{c}152.90 \mathrm{~d} \\
\pm 2.18\end{array}$ & $\begin{array}{c}155.04 \mathrm{e} \\
\pm 1.94\end{array}$ & $\begin{array}{c}164.48 d \\
\pm 0.80\end{array}$ & $\begin{array}{c}170.47 \mathrm{c} \\
\pm 1.90\end{array}$ & $\begin{array}{c}8.1 f \\
\pm 0.02\end{array}$ & $\begin{array}{l}8.12 f \\
\pm 0.02\end{array}$ & $\begin{array}{l}5.02 d \\
\pm 0.08\end{array}$ & $\begin{array}{l}5.07 e \\
\pm 0.10\end{array}$ \\
\hline $4 \mathrm{~g} / \mathrm{L} \mathrm{SE}$ & $\begin{array}{c}156.33 \mathrm{c} \\
\pm 1.38\end{array}$ & $\begin{array}{c}158.37 \mathrm{~d} \\
\pm 1.80\end{array}$ & $\begin{array}{c}166.42 \mathrm{~d} \\
\pm 1.12\end{array}$ & $\begin{array}{c}171.86 \mathrm{c} \\
\pm 4.72\end{array}$ & $\begin{array}{l}8.49 d \\
\pm 0.05\end{array}$ & $\begin{array}{c}8.53 \mathrm{de} \\
\pm 0.06\end{array}$ & $\begin{array}{l}5.47 \mathrm{~b} \\
\pm 0.12\end{array}$ & $\begin{array}{l}5.50 \mathrm{c} \\
\pm 0.09\end{array}$ \\
\hline $\begin{array}{c}3 \mathrm{~g} / \mathrm{L} \mathrm{FA}+3 \\
\mathrm{~g} / \mathrm{L} \mathrm{SE}\end{array}$ & $\begin{array}{c}162.58 \mathrm{~b} \\
\pm 0.97\end{array}$ & $\begin{array}{c}164.34 \mathrm{bc} \\
\pm 2.14\end{array}$ & $\begin{array}{c}173.6 \mathrm{c} \\
\pm 2.94\end{array}$ & $\begin{array}{c}177.38^{\mathrm{ab}} \\
\pm 2.57\end{array}$ & $\begin{array}{l}8.59^{b c} \\
\pm 0.04\end{array}$ & $\begin{array}{c}8.62 \mathrm{bcd} \\
\pm 0.05\end{array}$ & $\begin{array}{l}5.53 \mathrm{~b} \\
\pm 0.08\end{array}$ & $\begin{array}{l}5.58 \mathrm{bc} \\
\pm 0.05\end{array}$ \\
\hline $\begin{array}{c}3 \mathrm{~g} / \mathrm{L} \mathrm{FA}+4 \\
\mathrm{~g} / \mathrm{L} \mathrm{SE}\end{array}$ & $\begin{array}{l}164.22 \mathrm{~b} \\
\pm 1.55\end{array}$ & $\begin{array}{c}165.06 \mathrm{bc} \\
\pm 2.12\end{array}$ & $\begin{array}{c}175.85^{\mathrm{bc}} \\
\pm 0.46\end{array}$ & $\begin{array}{c}178.01 \mathrm{ab} \\
\pm 0.46\end{array}$ & $\begin{array}{l}8.63 \mathrm{~b} \\
\pm 0.10\end{array}$ & $\begin{array}{l}8.64 \mathrm{bc} \\
\pm 0.01\end{array}$ & $\begin{array}{l}5.51 \mathrm{~b} \\
\pm 0.11\end{array}$ & $\begin{array}{l}5.58 \mathrm{bc} \\
\pm 0.13\end{array}$ \\
\hline $\begin{array}{c}4 \mathrm{~g} / \mathrm{L} F A+3 \\
\mathrm{~g} / \mathrm{L} \mathrm{SE}\end{array}$ & $\begin{array}{c}164.23 b \\
\pm 0.93\end{array}$ & $\begin{array}{c}166.63 \mathrm{ab} \\
\pm 1.61\end{array}$ & $\begin{array}{c}178.25^{\mathrm{ab}} \\
\pm 3.04\end{array}$ & $\begin{array}{c}178.55 \mathrm{ab} \\
\pm 1.81\end{array}$ & $\begin{array}{l}8.65 b \\
\pm 0.05\end{array}$ & $\begin{array}{l}8.68 \mathrm{~b} \\
\pm 0.04\end{array}$ & $\begin{array}{l}5.54 b \\
\pm 0.02\end{array}$ & $\begin{array}{l}5.63 \mathrm{~b} \\
\pm 0.04\end{array}$ \\
\hline $\begin{array}{c}4 \mathrm{~g} / \mathrm{L} F A+4 \\
\mathrm{~g} / \mathrm{L} \mathrm{SE}\end{array}$ & $\begin{array}{c}167.46 a \\
\pm 1.02 \\
\end{array}$ & $\begin{array}{c}168.37 a \\
\pm 2.30\end{array}$ & $\begin{array}{c}180.19 a \\
\pm 1.63\end{array}$ & $\begin{array}{c}181.83 a \\
\pm 1.83\end{array}$ & $\begin{array}{c}8.8 \mathrm{a} \\
\pm 0.02 \\
\end{array}$ & $\begin{array}{c}8.9 a \\
\pm 0.13 \\
\end{array}$ & $\begin{array}{l}5.81 a \\
\pm 0.03 \\
\end{array}$ & $\begin{array}{l}6.14 \mathrm{a} \\
\pm 0.02 \\
\end{array}$ \\
\hline $\mathrm{LSD}_{0.05}$ & 2.83 & 2.41 & 4.08 & 4.56 & 0.09 & 0.11 & 0.13 & 0.11 \\
\hline
\end{tabular}

Table 5 shows that the weight of juice and pulp and fruit firmness were statistically increased by the soil application of FA or SE at 3 or $4 \mathrm{~g} / \mathrm{L}$ solely or in combinations in the two seasons. The effect of mixing of FA with SE have a higher effect on the same forementioned fruit characteristics than the single application of each one of, where the highest increments were obtained from $3 \mathrm{~g} / \mathrm{L} \mathrm{FA}+4 \mathrm{~g} / \mathrm{L} \mathrm{SE}, 4 \mathrm{~g} / \mathrm{L} \mathrm{FA}+3 \mathrm{~g} / \mathrm{L} \mathrm{SE}$, and 3 $\mathrm{g} / \mathrm{L} \mathrm{FA}+3 \mathrm{~g} / \mathrm{L} \mathrm{SE} \mathrm{g} / \mathrm{L}$. The impact of $4 \mathrm{~g} / \mathrm{L} \mathrm{FA}+4 \mathrm{~g} / \mathrm{L} \mathrm{SE}$ combination was superior as compared to the rest of the applied treatments and control in both experimental seasons. In contrast, the control treatment significantly increased the seed weight compared with the usage of FA or SE at 3 and $4 \mathrm{~g} / \mathrm{L}$ or their combinations in both experimental seasons. These results are in parallel with the results obtained by Haggag et al. (2016) on apricot and Taha et al. (2016) on apple, where they reported that spraying FA enhanced the fruit firmness. Additionally, Ravi et al. (2018) stated that spraying strawberry with SE improved bunch weight, hands, and fingers of banana cv. 'Grand Naine'. Spraying grape cv. 'Flame seedless' with FA at 1000, 1500, and 2000 ppm, and SE at 2000, 3000, and 4000 ppm, before flowering, during the full bloom, and three weeks later improved juice percentage of 100 berries and fruit firmness compared with the control (Harhash et al. 2021a). Similarly, Harhash et al. (2021b) found that the foliar application of FA at $0.2 \%, 0.3 \%$, and $0.4 \%$ on eight-year-old pomegranate cultivar cv. 'Wonderful' improved fruit firmness and juice weight. 
Table 5. Influence of Soil Application of SE and FA on Weight of Juice, Pulp, and Seed and Fruit Firmness of Guava cv. Maamoura

\begin{tabular}{|c|c|c|c|c|c|c|c|c|}
\hline \multirow[t]{2}{*}{ Treatment } & \multicolumn{2}{|c|}{$\begin{array}{l}\text { Juice Weight } \\
\text { (g) }\end{array}$} & \multicolumn{2}{|c|}{$\begin{array}{l}\text { Pulp Weight } \\
\text { (g) }\end{array}$} & \multicolumn{2}{|c|}{$\begin{array}{l}\text { Seed Weight } \\
\text { (g) }\end{array}$} & \multicolumn{2}{|c|}{$\begin{array}{l}\text { Fruit Firmness } \\
\left(\text { (lb/inch }^{2}\right)\end{array}$} \\
\hline & 2019 & 2020 & 2019 & 2020 & 2019 & 2020 & 2019 & 2020 \\
\hline Control & $\begin{array}{c}86.10 \mathrm{e} \\
\pm 1.47 \\
\end{array}$ & $\begin{array}{c}86.42 \mathrm{e} \\
\pm 1.59 \\
\end{array}$ & $\begin{array}{c}115.29 \mathrm{e} \\
\pm 2.22\end{array}$ & $\begin{array}{c}121.79 f \\
\pm 2.75\end{array}$ & $\begin{array}{c}21.68 \mathrm{a} \\
\pm 0.67 \\
\end{array}$ & $\begin{array}{c}21.69 a \\
\pm 1.19 \\
\end{array}$ & $\begin{array}{l}5.12 f \\
\pm 0.05 \\
\end{array}$ & $\begin{array}{l}5.15 f \\
\pm 0.06 \\
\end{array}$ \\
\hline $3 \mathrm{~g} / \mathrm{L} \mathrm{FA}$ & $\begin{array}{c}89.15 \mathrm{~cd} \\
\pm 1.05\end{array}$ & $\begin{array}{c}90.55 \mathrm{~d} \\
\pm 1.90\end{array}$ & $\begin{array}{c}136.16 \mathrm{c} \\
\pm 1.66\end{array}$ & $\begin{array}{c}136.73 \mathrm{de} \\
2.08\end{array}$ & $\begin{array}{c}19.27 \mathrm{c} \\
0.13\end{array}$ & $\begin{array}{c}20.09 b c \\
0.30\end{array}$ & $\begin{array}{c}5.88 d \\
0.02\end{array}$ & $\begin{array}{l}\text { 6.00de } \\
\pm 0.04\end{array}$ \\
\hline $4 \mathrm{~g} / \mathrm{L} \mathrm{FA}$ & $\begin{array}{c}91.34 \mathrm{bc} \\
2.18\end{array}$ & $\begin{array}{c}92.29 \mathrm{bc} \\
\pm 1.60\end{array}$ & $\begin{array}{c}144.41 \mathrm{~b} \\
\pm 2.60\end{array}$ & $\begin{array}{c}143.55 \mathrm{c} \\
\pm 1.01\end{array}$ & $\begin{array}{c}18.68 \mathrm{~d} \\
\pm 0.49\end{array}$ & $\begin{array}{c}19.41 \mathrm{~cd} \\
\pm 0.86\end{array}$ & $\begin{array}{l}5.92 d \\
\pm 0.03\end{array}$ & $\begin{array}{l}6.05 d \\
\pm 0.11\end{array}$ \\
\hline $3 \mathrm{~g} / \mathrm{L} \mathrm{SE}$ & $\begin{array}{c}88.55 \mathrm{de} \\
\pm 1.03\end{array}$ & $\begin{array}{c}89.43 d \\
\pm 1.00\end{array}$ & $\begin{array}{c}133.07 d \\
\pm 2.06\end{array}$ & $\begin{array}{c}134.05 \mathrm{e} \\
\pm 1.68\end{array}$ & $\begin{array}{c}19.83 b \\
0.17\end{array}$ & $\begin{array}{c}20.99 \mathrm{ab} \\
0.61\end{array}$ & $\begin{array}{l}5.72 e \\
\pm 0.07\end{array}$ & $\begin{array}{l}5.84 \mathrm{e} \\
\pm 0.10\end{array}$ \\
\hline $4 \mathrm{~g} / \mathrm{L} \mathrm{SE}$ & $\begin{array}{c}90.15^{\text {bcd }} \\
\pm 1.66\end{array}$ & $\begin{array}{l}90.61 \mathrm{~cd} \\
\pm 0.55\end{array}$ & $\begin{array}{c}137.50 \mathrm{c} \\
\pm 1.35\end{array}$ & $\begin{array}{c}138.50 \mathrm{~d} \\
1.47\end{array}$ & $\begin{array}{c}18.83 \mathrm{~cd} \\
\pm 0.07\end{array}$ & $\begin{array}{l}19.86 c \\
\pm 0.45\end{array}$ & $\begin{array}{l}5.92 d \\
\pm 0.02\end{array}$ & $\begin{array}{l}6.00 \mathrm{de} \\
\pm 0.09\end{array}$ \\
\hline $\begin{array}{c}3 \mathrm{~g} / \mathrm{L} \mathrm{FA}+3 \mathrm{~g} / \mathrm{L} \\
\mathrm{SE}\end{array}$ & $\begin{array}{c}91.44 \mathrm{bc} \\
\pm 1.09\end{array}$ & $\begin{array}{c}93.06 \mathrm{~b} \\
\pm 0.52\end{array}$ & $\begin{array}{c}144.73 b \\
\pm 0.58\end{array}$ & $\begin{array}{c}146.25 \mathrm{bc} \\
\pm 1.98\end{array}$ & $\begin{array}{c}17.85 \mathrm{e} \\
\pm 0.43\end{array}$ & $\begin{array}{c}19.38 \mathrm{~cd} \\
\pm 0.65\end{array}$ & $\begin{array}{l}6.08 \mathrm{c} \\
\pm 0.02\end{array}$ & $\begin{array}{l}6.07 d \\
\pm 0.06\end{array}$ \\
\hline $\begin{array}{c}3 \mathrm{~g} / \mathrm{L} \mathrm{FA}+4 \mathrm{~g} / \mathrm{L} \\
\mathrm{SE}\end{array}$ & $\begin{array}{c}92.24 a b \\
\pm 1.59 \\
\end{array}$ & $\begin{array}{c}93.27 \mathrm{~b} \\
\pm 0.54 \\
\end{array}$ & $\begin{array}{c}145.55 \mathrm{~b} \\
\pm 1.34 \\
\end{array}$ & $\begin{array}{c}146.55 \mathrm{~b} \\
\pm 2.24\end{array}$ & $\begin{array}{l}17.25 f \\
\pm 0.13 \\
\end{array}$ & $\begin{array}{c}18.51 \mathrm{de} \\
\pm 0.12 \\
\end{array}$ & $\begin{array}{l}6.29 \mathrm{~b} \\
\pm 0.05 \\
\end{array}$ & $\begin{array}{l}6.36 \mathrm{c} \\
\pm 0.10 \\
\end{array}$ \\
\hline $\begin{array}{c}4 \mathrm{~g} / \mathrm{L} \mathrm{FA}+3 \mathrm{~g} / \mathrm{L} \\
\mathrm{SE}\end{array}$ & $\begin{array}{c}94.49 a \\
\pm 1.01\end{array}$ & $\begin{array}{c}95.05 a \\
\pm 0.48\end{array}$ & $\begin{array}{c}146.97 b \\
\pm 1.54\end{array}$ & $\begin{array}{c}147.22 b \\
\pm 0.89\end{array}$ & $\begin{array}{l}17.33 f \\
\pm 0.15 \\
\end{array}$ & $\begin{array}{c}18.31 \mathrm{e} \\
\pm 0.12\end{array}$ & $\begin{array}{l}6.40 \mathrm{~b} \\
\pm 0.05\end{array}$ & $\begin{array}{l}6.57 \mathrm{~b} \\
\pm 0.15 \\
\end{array}$ \\
\hline $\begin{array}{c}4 \mathrm{~g} / \mathrm{L} \mathrm{FA}+4 \mathrm{~g} / \mathrm{L} \\
\mathrm{SE}\end{array}$ & $\begin{array}{c}94.61 \mathrm{a} \\
\pm 4.03 \\
\end{array}$ & $\begin{array}{c}95.51 \mathrm{a} \\
\pm 2.00 \\
\end{array}$ & $\begin{array}{c}150.13 a \\
\pm 0.91\end{array}$ & $\begin{array}{c}150.07 a \\
\pm 2.4\end{array}$ & $\begin{array}{l}17.07 f \\
\pm 0.09\end{array}$ & $\begin{array}{c}18.09 \mathrm{e} \\
\pm 0.21\end{array}$ & $\begin{array}{l}7.37 a \\
\pm 0.15\end{array}$ & $\begin{array}{l}7.6 \mathrm{a} \\
\pm 0.2\end{array}$ \\
\hline $\mathrm{LSD}_{0.05}$ & 2.56 & 1.72 & 2.95 & 2.79 & 0.50 & 1.05 & 0.11 & 0.20 \\
\hline
\end{tabular}

\section{Fruit Chemical Characteristics}

According to the results in Table 6, it was noticed that the soil application of FA and SE at 3 or $4 \mathrm{~g} / \mathrm{L}$ and their combinations improved TSS and vitamin C, while they decreased the juice acidity percentage in the two experimental seasons, and the influence of FA and SE increased by mixing them together. In addition, $4 \mathrm{~g} / \mathrm{L} \mathrm{FA}+4 \mathrm{~g} / \mathrm{L} \mathrm{SE}$ combination gave a significant increment in the percentage of TSS and fruit content from vitamin $\mathrm{C}$, while it reduced the juice acidity percentage comparing with the combinations of $3 \mathrm{~g} / \mathrm{L} \mathrm{FA}+3 \mathrm{SE} \mathrm{g} / \mathrm{L}, 3 \mathrm{~g} / \mathrm{L} \mathrm{FA}+4 \mathrm{~g} / \mathrm{L} \mathrm{SE}$, and $4 \mathrm{~g} / \mathrm{L} \mathrm{FA}+3 \mathrm{~g} / \mathrm{L} \mathrm{SE}$ in both seasons. On the opposite side, control treatment raised the percentage of juice acidity comparing with the rest applied treatments in the two seasons. The optimal treatment that achieved the best results was $4 \mathrm{~g} / \mathrm{L} \mathrm{FA}+4 \mathrm{~g} / \mathrm{L} \mathrm{SE}$ in the two seasons. The present obtained results are similar with those found by Suh et al. (2014). They reported that the application of FA on tomato raised soluble solids concentration and SSC/acidity ratio, while it minimized total acidity percent. In the same orientation, it was noticed that treating orange with SEs increased fruit content from vitamin C and TSS (Arioli et al. 2015; Gomathi et al. 2017). Moreover, the application of FA on grape cultivars such as 'Superior seedless' (El-Boray et al. 2015) with at $9 \mathrm{~mL} / \mathrm{L}$ per vine, 'Thompson seedless' (El-Kenawy 2017) with 500 ppm, 'King Ruby' (Mostafa et al. 2017) with 9 mL/L/vine and 'Flame seedless' (Harhash et al. 2021 a) with $2000 \mathrm{ppm}$ improved TSS, TSS/acid ratio, while it reduced the percentage of titratable acidity. Spraying of FA increased total soluble solids, and vitamin C, while it reduced the percentage of fruit juice acidity comparing with control in apricot (Haggag et al. 2016) and in apple (Khan et al. 2019). The application of SEs at 0, 2, 4, 8 g.L-1 on 'Albion' strawberry cultivar via fertigation system increased TSS, TSS/TA ratio, while 
decreased the fruit titratability acidity comparing with control were increased (Al-Shatri et al. 2020). Harhash et al. (2021b) found that spraying eight years old pomegranate cv. Wonderful with FA at $0.2 \%, 0.3 \%$, and $0.4 \%$, at the beginning of flowering, full bloom, and one month later three times increased total soluble solids, total reduced and nonreducing sugars, and TSS/acid ratio, while it minimized the percentages of fruit acidity as compared to the control.

Table 6. Influence of Soil Application of SE and FA on TSS and Acidity Percentages and Vitamin C in Guava cv. Maamoura

\begin{tabular}{|c|c|c|c|c|c|c|}
\hline \multirow{2}{*}{ Treatment } & \multicolumn{2}{|c|}{ TSS (\%) } & \multicolumn{2}{|c|}{ Acidity (\%) } & \multicolumn{2}{|c|}{$\begin{array}{c}\text { Vitamin C } \\
(\mathrm{mg} / 100 \mathrm{~mL})\end{array}$} \\
\hline & 2019 & 2020 & 2019 & 2020 & 2019 & 2020 \\
\hline Control & $\begin{array}{l}8.54 \mathrm{~h} \\
\pm 0.2\end{array}$ & $\begin{array}{l}9.55 \mathrm{~g} \\
\pm 0.12 \\
\end{array}$ & $\begin{array}{c}0.5 a \\
\pm 0.05\end{array}$ & $\begin{array}{l}0.51 \mathrm{a} \\
\pm 0.03 \\
\end{array}$ & $\begin{array}{c}175.93 \mathrm{e} \\
\pm 1.81\end{array}$ & $\begin{array}{c}176.91 \mathrm{f} \\
\pm 2.11 \\
\end{array}$ \\
\hline $3 \mathrm{~g} / \mathrm{L} \mathrm{FA}$ & $\begin{array}{l}10.33 f \\
\pm 0.05\end{array}$ & $\begin{array}{l}11.18 \mathrm{e} \\
\pm 0.04\end{array}$ & $\begin{array}{l}0.42 b \\
\pm 0.01\end{array}$ & $\begin{array}{l}0.44 b \\
\pm 0.01\end{array}$ & $\begin{array}{c}184.88 \mathrm{~d} \\
\pm 2.39\end{array}$ & $\begin{array}{c}182.82 \mathrm{de} \\
\pm 2.56\end{array}$ \\
\hline $4 \mathrm{~g} / \mathrm{L} \mathrm{FA}$ & $\begin{array}{l}11.92 d \\
\pm 0.15\end{array}$ & $\begin{array}{l}12.10 \mathrm{c} \\
\pm 0.14\end{array}$ & $\begin{array}{l}0.37 \mathrm{c} \\
0.006\end{array}$ & $\begin{array}{l}0.38 \mathrm{c} \\
\pm 0.02\end{array}$ & $\begin{array}{l}185.5 \mathrm{~d} \\
\pm 1.91\end{array}$ & $\begin{array}{c}185.19 \mathrm{de} \\
\pm 2.19\end{array}$ \\
\hline $3 \mathrm{~g} / \mathrm{L} \mathrm{SE}$ & $\begin{array}{l}9.6 \mathrm{~g} \\
0.25\end{array}$ & $\begin{array}{l}10.22 f \\
\pm 0.06\end{array}$ & $\begin{array}{l}0.49 a \\
\pm 0.04\end{array}$ & $\begin{array}{l}0.50 \mathrm{a} \\
\pm 0.04\end{array}$ & $\begin{array}{c}177.55 e \\
\pm 2.83\end{array}$ & $\begin{array}{c}181.84 \mathrm{e} \\
\pm 1.07\end{array}$ \\
\hline $4 \mathrm{~g} / \mathrm{L} \mathrm{SE}$ & $\begin{array}{l}11.25 \mathrm{e} \\
\pm 0.10\end{array}$ & $\begin{array}{c}11.57 d \\
\pm 0.18\end{array}$ & $\begin{array}{c}0.38 \mathrm{c} \\
\pm 0.006\end{array}$ & $\begin{array}{l}0.39 c \\
\pm 0.01\end{array}$ & $\begin{array}{c}185.42 \mathrm{~d} \\
\pm 1.00\end{array}$ & $\begin{array}{c}185.09 \mathrm{de} \\
2.37\end{array}$ \\
\hline $\begin{array}{c}3 \mathrm{~g} / \mathrm{L} \mathrm{FA}+3 \mathrm{~g} / \mathrm{L} \\
\mathrm{SE}\end{array}$ & $\begin{array}{l}12.6 c \\
\pm 0.31\end{array}$ & $\begin{array}{l}12.74 \mathrm{~b} \\
\pm 0.08\end{array}$ & $\begin{array}{c}0.36 \mathrm{c} \\
\pm 0.006\end{array}$ & $\begin{array}{l}0.37 c \\
\pm 0.01\end{array}$ & $\begin{array}{c}187.39 d \\
\pm 1.91\end{array}$ & $\begin{array}{c}185.89 d \\
\pm 1.14\end{array}$ \\
\hline $\begin{array}{c}3 \mathrm{~g} / \mathrm{L} \mathrm{FA}+4 \mathrm{~g} / \mathrm{L} \\
\mathrm{SE}\end{array}$ & $\begin{array}{c}12.67 \mathrm{c} \\
0.13\end{array}$ & $\begin{array}{c}12.99 \mathrm{~b} \\
\pm 0.19\end{array}$ & $\begin{array}{l}0.29 d \\
\pm 0.01\end{array}$ & $\begin{array}{l}0.32 d \\
\pm 0.01\end{array}$ & $\begin{array}{c}195.83 \mathrm{c} \\
\pm 1.09\end{array}$ & $\begin{array}{c}196.58 \mathrm{c} \\
\pm 2.15\end{array}$ \\
\hline $\begin{array}{c}4 \mathrm{~g} / \mathrm{L} \mathrm{FA}+3 \mathrm{~g} / \mathrm{L} \\
\mathrm{SE}\end{array}$ & $\begin{array}{l}13.61 \mathrm{~b} \\
\pm 0.36\end{array}$ & $\begin{array}{l}14.12 a \\
\pm 0.03\end{array}$ & $\begin{array}{l}0.29 d \\
\pm 0.02\end{array}$ & $\begin{array}{l}0.31 d \\
\pm 0.01\end{array}$ & $\begin{array}{c}200.09 \mathrm{~b} \\
\pm 2.94\end{array}$ & $\begin{array}{c}203.13 b \\
\pm 3.20\end{array}$ \\
\hline $\begin{array}{c}4 \mathrm{~g} / \mathrm{L} \mathrm{FA}+4 \mathrm{~g} / \mathrm{L} \\
\mathrm{SE}\end{array}$ & $\begin{array}{c}14.06 a \\
\pm 0.25\end{array}$ & $\begin{array}{l}14.2 \mathrm{a} \\
\pm 0.37\end{array}$ & $\begin{array}{l}0.24 \mathrm{e} \\
\pm 0.01\end{array}$ & $\begin{array}{c}0.26 \mathrm{e} \\
\pm 0.006\end{array}$ & $\begin{array}{c}207.42 \mathrm{a} \\
\pm 2.00\end{array}$ & $\begin{array}{c}208.11 \mathrm{a} \\
\pm 2.52\end{array}$ \\
\hline LSD0.05 $_{0.0}$ & 0.36 & 0.28 & 0.04 & 0.04 & 3.37 & 3.35 \\
\hline
\end{tabular}

From the results in Table 7, the addition of FA and SE to the soil greatly improved the fruit content from total, reduced, and non-reduced sugars compared to the control in the two seasons. This perhaps was because of their influence in raising the leaf total chlorophyll, TSS, and leaf surface area in the two seasons as well as their role in reducing the juice acidity percentages. Combining FA with SE was more effective in improving the fruit content from total, reduced and non-reduced sugars more than the individual addition of FA or SE in the two seasons. It was seen from the results that $4 \mathrm{~g} / \mathrm{L} \mathrm{FA}+4 \mathrm{~g} / \mathrm{L} \mathrm{SE}$ and $4 \mathrm{~g} / \mathrm{L}$ FA $+3 \mathrm{~g} / \mathrm{L}$ SE statistically increased these fruit chemical characteristics. Next in order of effectiveness were $3 \mathrm{~g} / \mathrm{L} \mathrm{FA}+4 \mathrm{~g} / \mathrm{L} \mathrm{SE}$ and $3 \mathrm{~g} / \mathrm{L} \mathrm{FA}+3 \mathrm{~g} / \mathrm{L} \mathrm{SE}$ as compared to control. These results are in parallel with the findings of (El-Miniawy et al. 2014; Kapur et al. 2018; Mattner et al. 2018). They stated that treating strawberry with SE increased crown carbohydrate. Similarly, spraying FA improved total carbohydrates in grape cvs. 'Thompson seedless' (El-Kenawy 2017) and 'King Ruby' (Mostafa et al. 2017). Kapur et al. (2018) found that the foliar application of SEs on strawberry improved the fruit chemical content from sucrose and fructose. In the same trend, it was found by Harhash et al. (2021a) that spraying grape cv. 'Flame seedless' with FA at 1000, 1500, and 2000 ppm, and with SE at 2000, 3000, and 4000 ppm before flowering, during the full bloom, and 
three weeks later improved the percentages of total sugars and total soluble solids as compared to the control in the two seasons. Moreover, in another study, it was reported that treatment of pomegranate cv. 'Wonderful' with FA improved the fruit content from total, reduced and non-reduced sugars compared with the control (Harhash et al. 2021b).

Table 7. Influence of Soil Application of SE and FA on the Percentages of the Total, Reduced, and Non-reduced Sugars in Guava cv. Maamoura

\begin{tabular}{|c|c|c|c|c|c|c|}
\hline \multirow{2}{*}{ Treatment } & \multicolumn{2}{|c|}{ Total Sugar (\%) } & \multicolumn{2}{|c|}{ Reduced Sugar (\%) } & \multicolumn{2}{|c|}{$\begin{array}{c}\text { Non reduced Sugar } \\
(\%)\end{array}$} \\
\hline & 2019 & 2020 & 2019 & 2020 & 2019 & 2020 \\
\hline Control & $\begin{array}{l}7.11 \mathrm{~h} \\
\pm 0.03\end{array}$ & $\begin{array}{l}7.19 g \\
\pm 0.04\end{array}$ & $\begin{array}{l}5.07 \mathrm{~g} \\
\pm 0.06\end{array}$ & $\begin{array}{l}5.13 f \\
\pm 0.03\end{array}$ & $\begin{array}{l}2.03 e \\
\pm 0.07\end{array}$ & $\begin{array}{l}2.06 f \\
\pm 0.06\end{array}$ \\
\hline $3 \mathrm{~g} / \mathrm{L} \mathrm{FA}$ & $\begin{array}{l}7.91 f \\
0.07\end{array}$ & $\begin{array}{r}7.97 f \\
\pm 0.13 \\
\end{array}$ & $\begin{array}{l}5.56 \mathrm{de} \\
\pm 0.10\end{array}$ & $\begin{array}{l}5.53 \mathrm{de} \\
\pm 0.13\end{array}$ & $\begin{array}{l}2.35 d \\
\pm 0.03\end{array}$ & $\begin{array}{l}2.45 \mathrm{e} \\
\pm 0.100\end{array}$ \\
\hline $4 \mathrm{~g} / \mathrm{L} \mathrm{FA}$ & $\begin{array}{l}8.57 e \\
\pm 0.02\end{array}$ & $\begin{array}{l}8.46 \mathrm{e} \\
\pm 0.09\end{array}$ & $\begin{array}{l}5.39 \mathrm{ef} \\
\pm 0.08\end{array}$ & $\begin{array}{l}5.43 e \\
\pm 0.07\end{array}$ & $\begin{array}{l}3.18 \mathrm{~b} \\
\pm 0.09\end{array}$ & $\begin{array}{l}3.03 \mathrm{c} \\
\pm 0.09\end{array}$ \\
\hline $3 \mathrm{~g} / \mathrm{L} \mathrm{SE}$ & $\begin{array}{l}7.63 \mathrm{~g} \\
\pm 0.02\end{array}$ & $\begin{array}{r}7.93 f \\
\pm 0.06\end{array}$ & $\begin{array}{l}5.25 f \\
\pm 0.08\end{array}$ & $\begin{array}{l}5.40 e \\
\pm 0.07\end{array}$ & $\begin{array}{l}2.37 d \\
\pm 0.06\end{array}$ & $\begin{array}{l}2.53 \mathrm{de} \\
\pm 0.12\end{array}$ \\
\hline $4 \mathrm{~g} / \mathrm{L} \mathrm{SE}$ & $\begin{array}{l}8.01 f \\
\pm 0.11\end{array}$ & $\begin{array}{l}8.09 f \\
\pm 0.12\end{array}$ & $\begin{array}{c}5.55 \mathrm{de} \\
\pm 0.09\end{array}$ & $\begin{array}{l}5.61 d \\
\pm 0.08\end{array}$ & $\begin{array}{l}2.46 \mathrm{~d} \\
\pm 0.06\end{array}$ & $\begin{array}{l}2.48 \mathrm{e} \\
\pm 0.06\end{array}$ \\
\hline $\begin{array}{c}3 \mathrm{~g} / \mathrm{L} \mathrm{FA}+3 \mathrm{~g} / \mathrm{L} \\
\mathrm{SE}\end{array}$ & $\begin{array}{l}8.83 d \\
\pm 0.07\end{array}$ & $\begin{array}{l}8.86 \mathrm{~d} \\
\pm 0.08\end{array}$ & $\begin{array}{l}5.69 d \\
\pm 0.11\end{array}$ & $\begin{array}{l}6.22 \mathrm{~b} \\
\pm 0.04\end{array}$ & $\begin{array}{l}3.14 b \\
\pm 0.06\end{array}$ & $\begin{array}{l}2.64 d \\
\pm 0.11\end{array}$ \\
\hline $\begin{array}{c}3 \mathrm{~g} / \mathrm{L} \mathrm{FA}+4 \mathrm{~g} / \mathrm{L} \\
\mathrm{SE}\end{array}$ & $\begin{array}{l}8.97 \mathrm{c} \\
\pm 0.14\end{array}$ & $\begin{array}{l}9.41 \mathrm{c} \\
\pm 0.15\end{array}$ & $\begin{array}{l}6.26 \mathrm{c} \\
\pm 0.07\end{array}$ & $\begin{array}{l}6.01 \mathrm{c} \\
\pm 0.09\end{array}$ & $\begin{array}{l}2.71 \mathrm{c} \\
\pm 0.18\end{array}$ & $\begin{array}{l}3.40 \mathrm{~b} \\
\pm 0.06\end{array}$ \\
\hline $\begin{array}{c}4 \mathrm{~g} / \mathrm{L} \mathrm{FA}+3 \mathrm{~g} / \mathrm{L} \\
\mathrm{SE}\end{array}$ & $\begin{array}{l}9.32 b \\
\pm 0.07 \\
\end{array}$ & $\begin{array}{l}9.68 \mathrm{~b} \\
\pm 0.15 \\
\end{array}$ & $\begin{array}{l}6.55 b \\
\pm 0.10\end{array}$ & $\begin{array}{l}6.55 \mathrm{a} \\
\pm 0.10\end{array}$ & $\begin{array}{l}2.77 c \\
\pm 0.07 \\
\end{array}$ & $\begin{array}{l}3.13 c \\
\pm 0.10 \\
\end{array}$ \\
\hline $\begin{array}{c}4 \mathrm{~g} / \mathrm{L} \mathrm{FA}+4 \mathrm{~g} / \mathrm{L} \\
\mathrm{SE}\end{array}$ & $\begin{array}{l}10.25 a \\
\pm 0.06\end{array}$ & $\begin{array}{c}9.85 a \\
\pm 0.1\end{array}$ & $\begin{array}{l}6.73 a \\
\pm 0.11\end{array}$ & $\begin{array}{l}6.22 b \\
\pm 0.10\end{array}$ & $\begin{array}{l}3.53 a \\
\pm 0.06\end{array}$ & $\begin{array}{l}3.63 a \\
\pm 0.10\end{array}$ \\
\hline LSD $_{0.05}$ & 0.14 & 0.16 & 0.17 & 0.15 & 0.16 & 0.14 \\
\hline
\end{tabular}

\section{Leaf Nitrogen (N), Phosphorous (P) and Potassium (K) Composition}

Leaf mineral composition from $\mathrm{N}, \mathrm{P}$, and $\mathrm{K}$ macronutrients was significantly increased by the soil application of SE or FA at 3 or $4 \mathrm{~g} / \mathrm{L}$ even when each was added alone or in combination compared with the control during the two seasons (Table 8). The combinations between FA and seaweed gave the most pronounced effect rather the single application. Moreover, the addition of $4 \mathrm{~g} / \mathrm{L} \mathrm{FA}+4 \mathrm{~g} / \mathrm{L} \mathrm{SE}$ statistically increased NPK leaf mineral content more than $4 \mathrm{~g} / \mathrm{L} \mathrm{FA}+3 \mathrm{~g} / \mathrm{L} \mathrm{SE}, 3 \mathrm{~g} / \mathrm{L} \mathrm{FA}+4 \mathrm{~g} / \mathrm{L} \mathrm{SE}$, and $3 \mathrm{~g} / \mathrm{L} \mathrm{FA}+3$ $\mathrm{g} / \mathrm{L} \mathrm{SE}$ in the two experimental seasons. Similar results were earlier obtained by Chen $e t$ al. (2004). Based on their findings, they stated that FA plays an important role in transporting the mineral nutrients directly to the sites of metabolism in the plant cells. In addition, because FA can increase significantly chelating, absorption, and distribution of elements in roots and shoots, it can encourage their growth (Bocanegra et al. 2006; Razavi, and BahramParvar 2007; Yildirim 2007; Yang et al. 2013; Canellas et al. 2015; Lotfi et al. 2015; Wang et al. 2019). Additionally, SE is rich in macro-nutrients including C, Mg, P, $\mathrm{K}$, and $\mathrm{S}$ and micronutrients such as $\mathrm{B}, \mathrm{Co}, \mathrm{F}, \mathrm{Mn}, \mathrm{Mo}, \mathrm{Se}, \mathrm{Si}, \mathrm{Zn}$ (Parthiban et al. 2013; Circuncisão et al. 2018), and it can increase the uptake of plants to soil nutrients (Renaut et al., 2019; EL Boukhari et al. 2020). Moreover, the results of the present experiment are in parallel with the findings of El-Miniawy et al. (2014), Kapur et al. (2018), and Mattner et al. 2018). They mentioned that the spray of strawberry with SE increased leaf mineral 
content of phosphorus and potassium. The foliar application of FA raised the leaf mineral content of nitrogen, phosphorous, potassium, zinc, manganese, and iron in comparison to the control in apricot (Haggag et al. 2016) and in apple (Taha et al. 2016; Khan et al. 2019). The foliar spraying of "Wonderful" pomegranate cultivar with FA at $0.2 \%, 0.3 \%$, and $0.4 \%$ raised the leaf mineral content from $\mathrm{N}, \mathrm{P}$, and $\mathrm{K}$ in the two seasons, as compared to control (Harhash et al. 2021b).

Table 8. Influence of Soil Application of SE and FA on Leaf Composition of N, P, and $\mathrm{K}$ in Guava cv. Maamoura

\begin{tabular}{|c|c|c|c|c|c|c|}
\hline \multirow{2}{*}{ Treatment } & \multicolumn{2}{|c|}{ N (\%) } & \multicolumn{2}{|c|}{$\mathbf{P}(\%)$} & \multicolumn{2}{|c|}{ K (\%) } \\
\hline & 2019 & 2020 & 2019 & 2020 & 2019 & 2020 \\
\hline Control & $\begin{array}{l}1.99 \mathrm{e} \\
\pm 0.04\end{array}$ & $\begin{array}{l}2.07 d \\
\pm 0.02\end{array}$ & $\begin{array}{l}0.31 \mathrm{e} \\
\pm 0.01\end{array}$ & $\begin{array}{l}0.31 d \\
\pm 0.01\end{array}$ & $\begin{array}{l}2.49 \mathrm{~g} \\
\pm 0.04\end{array}$ & $\begin{array}{r}2.56 f \\
\pm 0.03\end{array}$ \\
\hline $3 \mathrm{~g} / \mathrm{L} F A$ & $\begin{array}{l}2.11 d \\
\pm 0.03\end{array}$ & $\begin{array}{l}2.20 c \\
\pm 0.04\end{array}$ & $\begin{array}{l}0.36 \mathrm{~d} \\
\pm 0.01\end{array}$ & $\begin{array}{l}0.34 d \\
\pm 0.01\end{array}$ & $\begin{array}{l}2.72 f \\
\pm 0.07\end{array}$ & $\begin{array}{l}2.81 \mathrm{e} \\
\pm 0.05\end{array}$ \\
\hline $4 \mathrm{~g} / \mathrm{L} \mathrm{FA}$ & $\begin{array}{l}2.28 \mathrm{c} \\
\pm 0.06\end{array}$ & $\begin{array}{l}2.33 b \\
\pm 0.03\end{array}$ & $\begin{array}{c}0.39 \mathrm{~cd} \\
\pm 0.02\end{array}$ & $\begin{array}{l}0.41 \mathrm{c} \\
\pm 0.02\end{array}$ & $\begin{array}{l}3.01 \mathrm{e} \\
\pm 0.05\end{array}$ & $\begin{array}{l}3.05 d \\
\pm 0.04\end{array}$ \\
\hline $3 \mathrm{~g} / \mathrm{L} \mathrm{SE}$ & $\begin{array}{c}2.06 \mathrm{de} \\
\pm 0.02\end{array}$ & $\begin{array}{c}2.11 \mathrm{~cd} \\
\pm 0.04\end{array}$ & $\begin{array}{c}0.32 \mathrm{e} \\
0.01\end{array}$ & $\begin{array}{l}0.34 d \\
0.006\end{array}$ & $\begin{array}{l}2.71 f \\
\pm 0.05\end{array}$ & $\begin{array}{l}2.78 \mathrm{e} \\
\pm 0.09\end{array}$ \\
\hline $4 \mathrm{~g} / \mathrm{L} \mathrm{SE}$ & $\begin{array}{l}2.23 c \\
\pm 0.06\end{array}$ & $\begin{array}{l}2.31 b \\
\pm 0.04\end{array}$ & $\begin{array}{c}0.37 \mathrm{~cd} \\
\pm 0.01\end{array}$ & $\begin{array}{c}0.4 \mathrm{c} \\
\pm 0.04\end{array}$ & $\begin{array}{l}2.96 \mathrm{e} \\
\pm 0.08\end{array}$ & $\begin{array}{l}3.04 d \\
\pm 0.08\end{array}$ \\
\hline $3 \mathrm{~g} / \mathrm{L} F A+3 \mathrm{~g} / \mathrm{L} \mathrm{SE}$ & $\begin{array}{l}2.62 b \\
\pm 0.16\end{array}$ & $\begin{array}{l}2.72 \mathrm{a} \\
\pm 0.13\end{array}$ & $\begin{array}{c}0.39 \mathrm{~cd} \\
0.01\end{array}$ & $\begin{array}{l}0.42 \mathrm{c} \\
\pm 0.02\end{array}$ & $\begin{array}{c}3.47 d \\
0.05\end{array}$ & $\begin{array}{l}3.52 \mathrm{c} \\
\pm 0.03 \\
\end{array}$ \\
\hline $3 \mathrm{~g} / \mathrm{L} F A+4 \mathrm{~g} / \mathrm{L} \mathrm{SE}$ & $\begin{array}{l}2.66 \mathrm{~b} \\
\pm 0.04\end{array}$ & $\begin{array}{l}2.72 a \\
\pm 0.06\end{array}$ & $\begin{array}{c}0.40 c \\
0.02\end{array}$ & $\begin{array}{c}0.43 \mathrm{bc} \\
\pm 0.01\end{array}$ & $\begin{array}{l}3.88 \mathrm{c} \\
\pm 0.03\end{array}$ & $\begin{array}{l}3.98 \mathrm{~b} \\
\pm 0.06\end{array}$ \\
\hline $4 \mathrm{~g} / \mathrm{L} F A+3 \mathrm{~g} / \mathrm{L} S E$ & $\begin{array}{l}2.76 a \\
\pm 0.07\end{array}$ & $\begin{array}{l}2.79 \mathrm{a} \\
\pm 0.09\end{array}$ & $\begin{array}{c}0.44 b \\
0.02\end{array}$ & $\begin{array}{l}0.45 b \\
\pm 0.02\end{array}$ & $\begin{array}{l}3.99 b \\
\pm 0.05\end{array}$ & $\begin{array}{l}4.09 a \\
\pm 0.01\end{array}$ \\
\hline $4 \mathrm{~g} / \mathrm{L} F A+4 \mathrm{~g} / \mathrm{L} S E$ & $\begin{array}{l}2.85 a \\
\pm 0.10\end{array}$ & $\begin{array}{c}2.8 \mathrm{a} \\
\pm 0.02\end{array}$ & $\begin{array}{c}0.5 a \\
\pm 0.03\end{array}$ & $\begin{array}{l}0.51 a \\
\pm 0.03\end{array}$ & $\begin{array}{l}4.14 a \\
\pm 0.01\end{array}$ & $\begin{array}{l}4.18 \mathrm{a} \\
\pm 0.02\end{array}$ \\
\hline $\mathrm{LSD}_{0.05}$ & 0.10 & 0.09 & 0.03 & 0.03 & 0.10 & 0.09 \\
\hline
\end{tabular}

\section{CONCLUSIONS}

1. The soil application of fulvic acid (FA) and seaweed extract (SE), as well as their combinations, had significant effects in improving shoot length, shoot diameter, leaf area, and leaf total chlorophyll content when comparing results within two seasons.

2. The soil treating of the trees with FA and SE increased fruit set percentage, yield in $\mathrm{kg}$ per tree and in ton per hectare, as well as and fruit physical and chemical characteristics such as fruit weight, volume, firmness, and juice, TSS\%, total, reduced and nonreduced sugars, and vitamin $\mathrm{C}$, while they reduced that fruit acidity percentage comparing with control in both experimental seasons.

3. FA or SE can be used as safe and effective alternatives to the chemical fertilizers in the nutrition of fruit trees to produce safe food, keep the soil fertility, and reduce the environmental contamination. 


\section{ACKNOWLEDGMENTS}

This research was funded by the Researchers Supporting Project (RSP-2021/123) King Saud University, Riyadh, Saudi Arabia.

\section{REFERENCES CITED}

Abdel-Mawgoud, A. M., Lépine, F., and Déziel, E. (2010). "Rhamnolipids: Diversity of structures, microbial origins and roles," Applied Microbiology and Biotechnology 86(5), 1323-1336. DOI: 10.1007/s 00253-010-2498-2

Ali, O., Ramsubhag, A., and Jayaraman, J. (2019). "Biostimulatory activities of Ascophyllum nodosum extract in tomato and sweet pepper crops in a tropical environment,"Plos One 14(5), e0216710. DOI: 10.1371/journal.pone.0216710

Al-Ghamdi, A. A., and Elansary, H. O. (2018). "Synergetic effects of 5-aminolevulinic acid and Ascophyllum nodosum seaweed extracts on Asparagus phenolics and stress related genes under saline irrigation," Plant Physiology and Biochemistry 129, 273 284. DOI: 10.1016/j.plaphy.2018.06.008.

Al-Juthery, H. W., Drebee, H. A., Al-Khafaji, B. M., and Hadi, R. F. (2020). "Plant biostimulants, seaweeds extract as a model (article review)," in: IOP Conference Series: Earth and Environmental Science, 553(1), 012015.

DOI: $10.1088 / 1755-1315 / 553 / 1 / 012015$

Almaroai, Y. A., and Eissa, M. A. (2020). "Role of marine algae extracts in water stress resistance of onion under semiarid conditions," Journal of Soil Science and Plant Nutrition 20(3), 1092-1101. DOI: 10.1007/s42729-020-00195-0

Al-Musawi, M. A. H. M. (2018). "Effect of foliar application with algae extracts on fruit quality of sour orange, Citrus aurantium, L.," Journal of Environmental Science and Pollution Research 4(1), 250-252. DOI: 10.30799/jespr.122.18040104

Al-Shatri, A. H. N., Pakyürek, M., and Yavic, A. (2020). "Effect of seaweed application on the vegetative growth of strawberry cv. Albion grown under Iraq ecological conditions," Applied Ecology and Environmental Research 18(1), 1211-1225. DOI: 10.15666/aeer/1801_12111225

Anjum, S. A., Xie, X. Y., Wang, L.C., Saleem, M. F., Man, C., and Lei, W. (2011). "Morphological, physiological and biochemical responses of plants to drought stress," African Journal of Agricultural Research 6(9), 2026-2032.

DOI: 10.5897/AJAR10.027

Aremu, A. O., Plačková, L., Gruz, J., Bíba, O., Novák, O., Stirk, W. A., Dolezal, K., and Van Staden, J. (2016). "Seaweed-derived biostimulant (Kelpak®) influences endogenous cytokinins and bioactive compounds in hydroponically grown Eucomis autumnalis," Journal Plant Growth Regulation 35(1), 151-162. DOI: 10.1007/s00344-015-9515-8

Arioli, T., Mattner, S.W., and Winberg, P.C. (2015). "Applications of seaweed extracts in Australian agriculture: Past, present and future," Journal of Applied Phycology 27, 2007-2015. DOI: 10.1007/s10811-015-0574-9

Arrobas, M., Afonso, S., and Rodrigues, M. Â. (2018). "Diagnosing the nutritional condition of chestnut groves by soil and leaf analyses," Scientia Horticulturae 228, 113-121. DOI: 10.1016/j.scienta.2017.10.027 
Association of Official Analytical Chemist (AOAC) (2005). Official Methods of Analysis, $18^{\text {th }}$ Edition, AOAC International, Gaithersburg, MD, USA.

Basak, A. (2008). "Effect of preharvest treatment with seaweed products, Kelpak® and Goëmar BM 86®, on fruit quality in apple," International Journal of Fruit Science 8(1-2), 1-14. DOI: 10.1080/15538360802365251

Battacharyya, D., Babgohari, M. Z., Rathor, P., and Prithiviraj, B. (2015). "Seaweed extracts as biostimulants in horticulture," Scientia Horticulturae 196, 39-48. DOI: 10.1016/j.scienta.2015.09.012

Ben Salah, I., Aghrouss, S., Douira, A., Aissam, S., El Alaoui-Talibi, Z., Filali-Maltouf, A., and El Modafar, C. (2018). "Seaweed polysaccharides as bio-elicitors of natural defenses in olive trees against verticillium wilt of olive," Journal of Plant Interactions 13(1), 248-255. DOI: 10.1080/17429145.2018.1471528

Bocanegra, M. P., Lobartini, J. C., and Orioli, G. A. (2006). "Plant uptake of iron chelated by humic acids of different molecular weights," Communications in Soil Science and Plant Analysis 37(1-2), 239-248. DOI: 10.1080/00103620500408779

Bradáčová, K., Weber, N. F., Morad-Talab, N., Asim, M., Imran, M., Weinmann, M., and Neumann, G. (2016). "Micronutrients ( $\mathrm{Zn} / \mathrm{Mn})$, seaweed extracts, and plant growthpromoting bacteria as cold-stress protectants in maize," Chemical and Biological Technologies in Agriculture 3(1), 1-10. DOI: 10.1186/s40538-016-0069-1

Cabo, S., Morais, M. C., Aires, A., Carvalho, R., Pascual-Seva, N., Silva, A. P., and Gonçalves, B. (2019). "Kaolin and seaweed-based extracts can be used as middle and long-term strategy to mitigate negative effects of climate change in physiological performance of hazelnut tree," Journal of Agronomy and Crop Science 206(1), 28-42. DOI: $10.1111 /$ jac. 12369

Calvo, P., Nelson, L., and Kloepper, J. W. (2014). "Agricultural uses of plant biostimulants," Plant and Soil 383(1), 3-41. DOI: 10.1007/s11104-014-2131-8

Canellas, L. P., Olivares, F. L., Okorokova-Façanha, A. L., and Façanha, A. R. (2002). "Humic acids isolated from earthworm compost enhance root elongation, lateral root emergence, and plasma membrane H+-ATPase activity in maize roots," Plant Physiology 130(4), 1951-1957. DOI: 10.1104/pp.007088

Canellas, L. P., Olivares, F. L., Aguiar, N. O., Jones, D. L., Nebbioso, A., Mazzei, P., and Piccolo, A. (2015). "Humic and fulvic acids as biostimulants in horticulture," Scientia Horticulturae 196, 15-27. DOI: 10.1016/j.scienta.2015.09.013

Circuncisão, A. R., Catarino, M. D., Cardoso, S. M., and Silva, A. (2018). "Minerals from macroalgae origin: Health benefits and risks for consumers," Marine Drugs 16(11), 1-30. DOI: 10.3390/md16110400

Chen, Y., Clapp C. E., and Magen, H. (2004). "Mechanisms of plant growth stimulation by humic substances: The role of organo-iron complexes," Soil Science and Plant Nutrition 50(7), 1089-1095. DOI: 10.1080/00380768.2004.10408579

Chouliaras, V., Tasioula, M., Chatzissavvidis, C., Therios, I., and Tsabolatidou, E. (2009). "The effects of a seaweed extract in addition to nitrogen and boron fertilization on productivity, fruit maturation, leaf nutritional status and oil quality of the olive (Olea europaea L.) cultivar Koroneiki," Journal of the Science of Food and Agriculture 89(6), 984-988. DOI: 10.1002/jsfa.3543

Colavita, G. M., Spera, N., Blackhall, V. and Sepulveda, G. M. (2011). "Effect of seaweed extract on pear fruit quality and yield," Acta Horticulturae 909, 601-607 DOI: 10.17660/ActaHortic.2011.909.72 
Craigie, J. S. (2011). "Seaweed extract stimuli in plant science and agriculture," Journal of Applied Phycology 23(3), 371-393. DOI: 10.1007/s10811-010-9560-4

Demirsoy, H. (2009). "Leaf area estimation in some species of fruit tree by using models as a non-destructive method," Fruits 64(1), 45-51. DOI: 10.1051/fruits/2008049

de Sousa, A. M., Ayub, R. A., Viencz T., and Botelho, R. V. (2019). "Fruit set and yield of apple trees cv. Gala treated with seaweed extract of Ascophyllum nodosum and thidiazuron," Revista Brasileira de Fruticultura 41(1), (e-072). DOI: 10.1590/010029452019072

Duan, Y., Xu, M., Gao, S., Liu, H., Huang, S., and Wang, B. (2016). “Long-term incorporation of manure with chemical fertilizers reduced total nitrogen loss in rainfed cropping systems," Scientific Reports 6(1), 1-10. DOI: 10.1038/srep33611

Elansary, H. O., Norrie, J., Ali, H. M., Salem, M. Z. M., Mahmoud, E. A., and Yessoufou, K. (2016). "Enhancement of Calibrachoa growth, secondary metabolites and bioactivity using seaweed extracts," BMC Complementary and Alternative Medicine 16, article no. 341. DOI: 10.1186/s12906-016-1332-5

El-Boray, M. S., Mostafa, M. F., Shaltout, A. D., and Hassan, K. H. (2015). "Influence of fulvic acid plus some microelements and microorganisms on yield and quality characteristics of superior seedless grapevines," Journal of Plant Production 6(3), 287-305. DOI: 10.21608/jpp.2015.49320

El-Boukhari, M. E., Barakate, M., Bouhia, Y., and Lyamlouli, K. (2020). "Trends in seaweed extract based biostimulants: Manufacturing process and beneficial effect on soil-plant systems," Plants 9(359), 1-23. DOI: 10.3390/plants9030359

El-Helaly, M. A. (2018). "Effect of foliar application of humic and fulvic acids on yield and its components of some carrot (Daucus carota L.) cultivars," Journal of Horticultural Science \& Ornamental Plants 10(3), 159-166. DOI: 10.5829/idosi.jhsop.2018.159.166

El-kenawy, M. A. (2017). "Effect of chitosan, salicylic acid and fulvic acid on vegetative growth, yield and fruit quality of Thompson seedless grapevines," Egyptian Journal of Horticulture 44(1), 45-59. DOI: 10.21608/EJOH.2017.1104.1007

El-Miniawy, S. M., Ragab, M. E., Youssef, S. M., and Metwally, A. A. (2014). "Influence of foliar spraying of seaweed extract on growth, yield and quality of strawberry plants," Journal of Applied Sciences Research 10(2), 88-94.

El-Sharony, T. F., El-Gioushy, S. F., ans Amin, O. A. (2015). "Effect of foliar application with algae and plant extracts on growth, yield and fruit quality of fruitful mango trees cv. Fagri Kalan," Journal of Horticulture 2(4),1-6. DOI:10.4172/2376-0354.1000162

Eyheraguibel, B., Silvestre, J., and Morard, P. (2008). "Effects of humic substances derived from organic waste enhancement on the growth and mineral nutrition of maize," Bioresource Technology 99(10), 4206-4212. DOI: 10.1016/j.biortech.2007.08.082

Fan, D., Hodges, D. M., Critchley, A. T., and Prithiviraj, B. (2013). "A commercial extract of brown macroalga (Ascophyllum nodosum) affects yield and the nutritional quality of spinach in vitro," Communications in Soil Science and Plant Analysis 44(12), 1873-1884. DOI: 10.1080/00103624.2013.790404

Gomathi, R., Kohila, S., and Ramachandiran, K. (2017). "Evaluating the effect of seaweed formulations on the quality and yield of sugarcane," Madras Agricultural Journal 104 (4-6), 161-165, DOI:10.29321/MAJ 2019.000213 
Gupta, V., Kumar, M., Brahmbhatt, H., Reddy, C. R. K., Seth, A., and Jha, B. (2011). "Simultaneous determination of different endogenetic plant growth regulators in common green seaweeds using dispersive liquid-liquid microextraction method," Plant Physiology and Biochemistry 49(11), 1259-1263. DOI:

10.1016/j.plaphy.2011.08.004

Haggag, L. F., Fawzi, M., Shahin, M. and EL-Hady, E. S. (2016). "Effect of yeast, humic acid, fulvic acid, citric acid, potassium citrate and some chelated micro-elements on yield, fruit quality and leaf minerals content of "Canino" apricot trees," International Journal Chemistry Technology Research 9(4), 07-15.

Harhash M. M., Abd EL-Megeed N. A., Abaidalah A. S., and Mosa W. F. A. (2021a). "Effect of the foliar spraying of fulvic acid, folic acid, and seaweed extract on vegetative growth, yield and fruit quality of grape cv. Flame seedless," Plant Archives 21(1), 482-492. DOI: 10.51470/PLANTARCHIVES.2021.v21.no1.068

Harhash M. M., Saad R. M., and Mosa W. F. A. (2021b). "Response of "Wonderful" pomegranate cultivar to the foliar application of some biostimulants," Plant Archives (in press).

Hayyawi, N. J. H., Al-Issawi, M. H., Alrajhi, A. A., Al-Shmgani, H., and Rihan, H. (2020). "Molybdenum induces growth, yield, and defense system mechanisms of the mung bean (Vigna radiata L.) under water stress conditions," International Journal of Agronomy 2020, article no. 8887329. DOI: 10.1155/2020/8887329

Huang, S., Xiong, B., Sun, G., He, S., Liao, L., Wang, J., Wang, B., and Wang, Z. (2020). "Effects of fulvic acid on photosynthetic characteristics of citrus seedlings under drought stress," IOP Conference Series: Earth and Environmental Science 474(2020). DOI: $10.1088 / 1755-1315 / 474 / 3 / 032007$

Hui, L. I., Feng, W. T., He, X. H., Ping, Z. H. U., Gao, H. J., Nan, S. U. N., and Xu, M. G. (2017). "Chemical fertilizers could be completely replaced by manure to maintain high maize yield and soil organic carbon (SOC) when SOC reaches a threshold in the Northeast China Plain," Journal of Integrative Agriculture 16(4), 937-946. DOI: 10.1016/S2095-3119(16)61559-9

Justi, M., Morais, E. G., and Silva, C. A. (2019). "Fulvic acid in foliar spray is more effective than humic acid via soil in improving coffee seedlings growth," Archives of Agronomy and Soil Science 65(14), 3-17. DOI: 10.1080/03650340.2019.1584396

Kapur, B., Sarıdaş, M. A., Çeliktopuz, E., Kafkas, E., and Kargı, S. P. (2018). "Health and taste related compounds in strawberries under various irrigation regimes and biostimulant application," Food Chemistry 263, 67-73. DOI: 10.1016/j.foodchem.2018.04.108

Khan, O. A., Sofi, J. A., Kirmani, N. A., Hassan, G. I., Bhat, S. A., Chesti, M. H., and Ahmad, S. M. (2019). "Effect of N, P and K Nano-fertilizers in comparison to humic and fulvic acid on yield and economics of red delicious (Malus domestica Borukh.)," Journal of Pharmacognosy and Phytochemistry 8(2), 978-981

Khan, W., Rayirath, U. P., Subramanian, S., Jithesh, M. N., Rayorath, P., Hodges, D. M., Critchley, A. T., Craigie, J. S., Norrie, J., and Prithiviraj, B. (2009). "Seaweed extracts as biostimulants of plant growth and development," Journal of Plant Growth Regulation 28(4), 386-399. DOI: 10.1007/s00344-009-9103-x 
Khan, Z. H., Khan, M. M. A., Aftab, T., Idrees, M., and Naeem, M. (2011). "Influence of alginate oligosaccharides on growth, yield and alkaloid production of opium poppy (Papaver somniferum L.)," Frontiers of Agriculture in China 5(1), 122-127.

DOI: $10.1007 / \mathrm{s} 11703-010-1056-0$

Khompatara, K., Pettongkhao, S., Kuyyogsuy, A., Deenamo, N., and Churngchow, N. (2019). "Enhanced resistance to leaf fall disease caused by Phytophthora palmivora in rubber tree seedling by Sargassum polycystum extract," Plants 8(6), 1-14. DOI: 10.3390/plants8060168

Kocira, A., Świeca, M., Kocira, S., Złotek, U., and Jakubczyk, A. (2018). “Enhancement of yield, nutritional and nutraceutical properties of two common bean cultivars following the application of seaweed extract (Ecklonia maxima)," Saudi Journal of Biological Sciences 25(3), 563-571. DOI: 10.1016/j.sjbs.2016.01.039

Kulkarni, M. G., Rengasamy, K. R. R., Pendota, S. C., Gruz, J., Plačková, L., Novák, O., Doležal, K., and Van Staden, J. (2019). "Bioactive molecules derived from smoke and seaweed Ecklonia maxima showing phytohormone-like activity in Spinacia oleracea L.," New Biotechnology 48, 83-89. DOI: 10.1016/j.nbt.2018.08.004

Lall, D., Prasad, V. M., Singh, V. K., and Kiishor, S. (2017). "Effect of foliar application of Biovita (biofertilizer) on fruit set, yield and quality of guava (Psidium guajava L.)," Research in Environment and Life Science 10(5), 432-434.

Li, M.-S., Li, S., Zhang, S.-Y., and Chi, B.-L. (2005). "Physiological effect of new FA antitranspirant application on winter wheat at ear filling stage," Chinese Agriculture Science 38(4), 703-708.

Liu, X., Zhang, Y., Han, W., Tang, A., Shen, J., Cui, Z., Vitousek, P., Erisman, J.W., Goulding, K., Christie, P. and Zhang, F. (2013). "Enhanced nitrogen deposition over China," Nature 494(7438), 459-462. DOI: 10.1038/nature11917

Lotfi, R., Pessarakli, M., Gharavi-Kouchebagh, P., and Khoshvaghti, H. (2015). "Physiological responses of Brassica napus to fulvic acid under water stress: Chlorophyll a fluorescence and antioxidant enzyme activity," The Crop Journal 3(5), 434-439. DOI: 10.1016/j.cj.2015.05.006

Lu, J. W., and Beamish, P. W. (2001). "The internationalization and performance of SMEs," Strategic Management Journal 22(6-7), 565-586. DOI: 10.1002/smj.184

Machado, L. P., Matsumoto, S. T., Jamal, C. M., da Silva, M. B., da Cruz Centeno, D., Neto, P. C., de Carvalho, L.R., and Yokoya, N. S. (2014). "Chemical analysis and toxicity of seaweed extracts with inhibitory activity against tropical fruit anthracnose fungi," Journal of the Science of Food and Agriculture 94(9), 1739-1744. DOI: $10.1002 /$ jsfa.6483

Mackowiak, C., Grossl, P., and Bugbee, B. (2001). "Beneficial effects of humic acid on micronutrient availability to wheat," Soil Science Society of America Journal 65(6), 1744-1750. DOI: 10.2136/sssaj2001.1744

Mancuso, S., Azzarello, E., Mugnai, S., and Briand, X. (2006). "Marine bioactive substances (IPA extract) improve foliar ion uptake and water stress tolerance in potted Vitis vinifera plants," Advances in Horticultural Science 20(2), 156-161.

Mattner, S. W., Milinkovic, M., and Arioli, T. (2018). "Increased growth response of strawberry roots to a commercial extract from Durvillaea potatorum and Ascophyllum nodosum," J. Applied Phycology 30, 2943-2951. DOI: 10.1007/s10811-017-1387-9

Mostafa, M. F. M., EL-Boray, M. S., El-Baz, E. L., and Omar, A. S. (2017). "Effect of fulvic acid and some nutrient elements on king ruby grapevines growth, yield and chemical properties of berries," Journal of Plant Production 8(2), 321-328. DOI: 


\subsection{8/jpp.2017.39630}

Nardi, S., Pizzeghello, D., Muscolo, A., and Vianello, A. (2002). "Physiological effects of humic substances on higher plants," Soil Biology and Biochemistry 34(11), 15271536. DOI: 10.1016/S0038-0717(02)00174-8

Neumann, D., and Zur Nieden, U. (2001). "Silicon and heavy metal tolerance of higher plants," Phytochemistry 56(7), 685-692. DOI: 10.1016/S0031-9422(00)00472-6

Ni, B., Liu, M., Lu, S., Xie, L., and Wang, Y. (2011). "Environmentally friendly slowrelease nitrogen fertilizer," Journal of Agricultural and Food Chemistry 59(18), 10169-10175. DOI: $10.1021 / \mathrm{jf} 202131 \mathrm{z}$

Nielsen, S. S. (2010). "Phenol-sulfuric acid method for total carbohydrates," in: Food Analysis Laboratory Manual, S. S. Nielsen (ed.), Springer, Boston, MA, USA, pp. 47-53. DOI: $10.1007 / 978-1-4419-1463-7$

Nielsen, S. S. (2017). "Vitamin C determination by indophenol method," in: Food Analysis Laboratory Manual, S S. Nielsen (ed.), Springer, Boston, MA, USA, 143146. DOI: 10.1007/978-3-319-44127-6_32

Ning, C. C., Gao, P. D., Wang, B. Q., Lin, W. P., Jiang, N. H., and Cai, K. Z. (2017). "Impacts of chemical fertilizer reduction and organic amendments supplementation on soil nutrient, enzyme activity and heavy metal content," Journal of Integrative Agriculture 16(8), 1819-1831. DOI: 10.1016/S2095-3119(16)61476-4

Ott, R. L., and Longnecker, M. T. (2015). An Introduction to Statistical Methods and Data Analysis, Cengage Learning, Boston, MA, USA.

Parthiban, C., Saranya, C., Girija, K., Hemalatha, A., Suresh, M., and Anantharaman, P. (2013). "Biochemical composition of some selected seaweeds from Tuticorin coast," Advances in Applied Science Research 4(3), 362-366.

Patel, R. V., Pandya, K. Y., Jasrai, R. T., and Brahmbhatt, N. (2018). "Significance of green and brown seaweed liquid fertilizer on seed germination of Solanum melongena, Solanum lycopersicum and Capsicum annum by paper towel and pot method," International Journal of Recent Scientific Research 9, 24065-24072.

Piccolo, A., and Mbagwu, J. S. C. (1999). "Role of hydrophobic components of soil organic matter in soil aggregate stability," Soil Science Society of America Journal 63(6), 1801-1810. DOI: 10.2136/sssaj1999.6361801x

Prasad, K., Das, A. K., Oza, M. D., Brahmbhatt, H., Siddhanta, A. K., Meena, R., Eswaran, K., Rajyaguru, M. R., and Ghosh, P. K. (2010). "Detection and quantification of some plant growth regulators in a seaweed-based foliar spray employing a mass spectrometric technique sans chromatographic separation," Journal of Agricultural and Food Chemistry 58(8), 4594-4601. DOI: 10.1021/jf904500e

Priya, B. N. V., Mahavishnan K., Gurumurthy D. S., Bindumadhava H., Upadhyay A. P., and Sharma N.K. (2014). "Fulvic acid (FA.) for enhanced nutrient uptake and growth: Insights from biochemical and genomic studies," Journal of Crop Improvement, 28(6), 740-757. DOI:10.1080/15427528.2014.923084

Rathore, S. S., Chaudhary, D. R., Boricha, G. N., Ghosh, A., Bhatt, B. P., Zodape, S. T., and Patolia, J. S. (2009). "Effect of seaweed extract on the growth, yield and nutrient uptake of soybean (Glycine max) under rainfed conditions," South African Journal of Botany 75(2), 351-355. DOI: 10.1016/j. sajb.2008.10.009

Ravi, I., Kamaraju, K., Kumar, S., and Nori, S. S. (2018). "Foliar application of seaweed bio formulation enhances growth and yield of banana cv. Grand Naine (AAA)," Indian Journal of Natural Sciences 8(47), 13482-13488.

Razavi, S. M. A., and BahramParvar, M. (2007). "Some physical and mechanical 
properties of kiwifruit," International Journal of Food Engineering 3(6), 1-14. DOI: 10.2202/1556-3758.1276

Renaut, S., Masse, J., Norrie, J. P., Blal, B., and Hijri, M. (2019). “A commercial seaweed extract structured microbial communities associated with tomato and pepper roots and significantly increased crop yield," Microbial Biotechnology 12(6),13461358. DOI: $10.1111 / 1751-7915.13473$

Rioux, L. E., Turgeon, S. L., and Beaulieu, M. (2009). "Effect of season on the composition of bioactive polysaccharides from the brown seaweed Saccharina longicruris," Phytochemistry 70(8), 1069-1075. DOI: 10.1016/j.phytochem.2009.04.020

Rouphael, Y., Giordano, M., Cardarelli, M., Cozzolino, E., Mori, M., Kyriacou, M. C., Bonini, P., and Colla, G. (2018). "Plant-and seaweed-based extracts increase yield but differentially modulate nutritional quality of greenhouse spinach through biostimulant action," Agronomy 8(126), 1-15. DOI: 10.3390/agronomy8070126

Samavat, S., and Samavat, S. (2014). "The effects of fulvic acid and sugar cane molasses on yield and qualities of tomato," International Research Journal of Applied Basic Sciences 8(3), 266-268.

Schmidt, W., Santi, S., Pinton, R., and Varanini, Z. (2007). "Water-extractable humic substances alter root development and epidermal cell pattern in Arabidopsis," Plant and Soil 300(1), 259-267. DOI: 10.1007/s11104-007-9411-5

Sierra, J., Causeret, F., Diman, J. L., Publicol, M., Desfontaines, L., Cavalier, A., and Chopin, P. (2015). "Observed and predicted changes in soil carbon stocks under export and diversified agriculture in the Caribbean. The case study of Guadeloupe," Agriculture, Ecosystems and Environment 213, 252-264. DOI: 10.1016/j.agee.2015.08.015

Sivasankari, S., Venkatesalu, V., Anantharaj, M., and Chandrasekaran, M. (2006). "Effect of seaweed extracts on the growth and biochemical constituents of Vigna sinensis," Bioresource Technology 97(14), 1745-1751.

DOI: $10.1016 /$ j.biortech.2005.06.016

Smith, L. E., and Siciliano, G. (2015). "A comprehensive review of constraints to improved management of fertilizers in China and mitigation of diffuse water pollution from agriculture," Agriculture, Ecosystems and Environment 209, 15-25. DOI: 10.1016/j.agee.2015.02.016

Soppelsa, S., Kelderer, M., Casera, C., Bassi, M., Robatscher, P., and Andreotti, C. (2018). "Use of biostimulants for organic apple production: effects on tree growth, yield, and fruit quality at harvest and during storage," Frontiers in Plant Science 9(1342), 1-17. DOI: $10.3389 /$ fpls.2018.01342

Sparks, D. L., Page, A. L., Helmke, P. A., and Loeppert, R. H. (2016). Methods of Soil Analysis, Part 3: Chemical Methods, John Wiley \& Sons, Hoboken, NJ, USA.

Stirk, W. A., and Van Staden, J. (2014). "Plant growth regulators in seaweeds: Occurrence, regulation and functions," Advances in Botanical Research 71, 125-159. DOI: 10.1016/B978-0-12-408062-1.00005-6

Stirk, W., Novák, O., Strnad, M., and Van Staden, J. (2003). "Cytokinins in macroalgae," Plant Growth Regulation 41(1), 13-24. DOI: 10.1023/A:1027376507197

Stuart, D., Schewe, R. L., and McDermott, M. (2014). "Reducing nitrogen fertilizer application as a climate change mitigation strategy: Understanding farmer decisionmaking and potential barriers to change in the US," Land Use Policy 36, 210-218. DOI: 10.1016/j.landusepol.2013.08.011

Suh, H. Y., Yoo, K. S., and Suh, S. G. (2014). "Effect of foliar application of fulvic acid 
on plant growth and fruit quality of tomato (Lycopersicon esculentum L.)," Horticulture, Environment, Biotechnology 55(6), 455-461. DOI: 10.1007/s13580-014-0004-y

Suhag, M. (2016). "Potential of biofertilizers to replace chemical fertilizers," International Advanced Research Journal in Science, Engineering and Technology 3(5), 163-167. DOI 10.17148/IARJSET.2016.3534.

Taha, A. A., Omar, M. M., and Ghazy, M. A. (2016). "Effect of humic and fulvic acids on growth and yield of lettuce plant," Journal of Soil Sciences and Agricultural Engineering 7(8), 517-522. DOI: 10.21608/jssae.2016.39782

Uphoff, N., and Dazzo, F. B. (2016). "Making rice production more environmentallyfriendly," Environments 3(12), 1-7. DOI: 10.3390/environments3020012

Valencia, R. T., Acosta, L. S., Hernández, M. F., Rangel, P. P., Robles, M. Á. G., Rocío del Cruz, A., and Vázquez, C.V. (2018). "Effect of seaweed aqueous extracts and compost on vegetative growth, yield, and nutraceutical quality of cucumber (Cucumis sativus L.) fruit," Agronomy, 8(264), 1-3. DOI: 10.3390/agronomy8110264

Wang, H., Pampati, N., McCormick, W. M., and Bhattacharyya, L. (2016). "Protein nitrogen determination by Kjeldahl digestion and ion chromatography," Journal of Pharmaceutical Sciences 105(6), 1851-1857. DOI: 10.1016/j.xphs.2016.03.039

Wang, Y., Yang, R., Zheng, J., Shen, Z., and Xu, X. (2019). "Exogenous foliar application of fulvic acid alleviate cadmium toxicity in lettuce (Lactuca sativa L.)," Ecotoxicology and Environmental Safety 167, 10-19.

DOI: 10.1016/j.ecoenv.2018.08.064.

Wang, Y., Zhu, Y., Zhang, S., and Wang, Y. (2018). "What could promote farmers to replace chemical fertilizers with organic fertilizers?" Journal of Cleaner Production 199, 882-890. DOI: 10.1016/j.jclepro.2018.07.222

Wassel, A. M. M., Gobara A. A., Rizk E. A., and El-Wany A. R. M. (2014). "Reducing mineral $\mathrm{N}$ fertilizer partially in 'Thompson Seedless' vineyards by using fulvic acid and effective microorganisms," World Rural Observ. 6(4), 36-42.

Weiwei, C., Jinrong, L., Fang, X., and Jing, L. (2017). "Improvement to the determination of activated phosphorus in water and wastewater by yellow vanadomolybdate method," Industrial Water Treatment 37(2), 95-97.

DOI: 10.11894/1005-829x.2017.37(2).095

Yalçın, S., Şükran Okudan, E., Karakaş, Ö., Önem, A. N., and Başkan, K. S. (2019). "Identification and quantification of some phytohormones in seaweeds using UPLCMS/MS," Journal of Liquid Chromatography \& Related Technologies, 42(15-16), 110. DOI: $10.1080 / 10826076.2019 .1625374$

Yang, S., Zhang, Z., Cong, L., Wang, X., and Shi, S. (2013). "Effect of fulvic acid on the phosphorus availability in acid soil," Journal of Soil Science and Plant Nutrition 13(3), 526-533. DOI: 10.4067/S0718-95162013005000041

Yildirim, E. (2007). "Foliar and soil fertilization of humic acid affect productivity and quality of tomato," Acta Agriculturae Scandinavica Section B-Soil and Plant Science 57(2), 182-186. DOI: 10.1080/09064710600813107

Youssef, M. M. A., and Eissa, M. F. M. (2014). "Biofertilizers and their role in management of plant parasitic nematodes (A review)," Journal of Biotechnology and Pharmaceutical Research 5(1), 1-6.

Zhang, X., and Ervin, E. (2004). "Cytokinin-containing seaweed and humic acid extracts associated with creeping bentgrass leaf cytokinins and drought resistance," Crop Science 44(5), 1737-1745. DOI: 10.2135/cropsci2004.1737 
Zimmerli, L., Hou, B. H., Tsai, C. H., Jakab, G., Mauch-Mani, B., and Somerville, S. (2008). "The xenobiotic $\beta$-aminobutyric acid enhances Arabidopsis thermotolerance," The Plant Journal 53(1), 144-156. DOI: 10.1111/j.1365-313X.2007.03343

Zodape, S. T., Gupta, A., Bhandari, S. C., Rawat, U. S., Chaudhary, D. R., Eswaran, K., and Chikara, J. (2011). "Foliar application of seaweed sap as biostimulant for enhancement of yield and quality of tomato (Lycopersicon esculentum Mill.)," Journal of Scientific \& Industrial Research 70(3), 215-219.

Article submitted: July 31, 2021; Peer review completed: September 5, 2021; Revised version received and accepted: September 14, 2021; Published: September 17, 2021.

DOI: 10.15376/biores. 16.4.7379-7399 